\title{
COMMUNITY POLICING IN DURHAM REGION: IMPLICATIONS FOR DIVERSE ETHNIC GROUPS
}

\author{
by
}

Sheldon Funk, Honors BA, University of Ontario Institute of Technology 2012

\author{
A Major Research Project \\ Presented to Ryerson University \\ in partial fulfillment of the requirements for the degree of \\ Master of Arts \\ in the program of \\ Immigration and Settlement Studies
}

Toronto, Ontario, Canada

(C) Sheldon Funk 2014 


\section{AUTHOR'S DECLARATION FOR ELECTRONIC SUBMISSION OF A MAJOR RESEARCH PAPER (MRP)}

I hereby declare that I am the sole author of this Major Research Paper. This is a true copy of the MRP, including any required final revisions, as accepted by my examiners.

I authorize Ryerson University to lend this MRP to other institutions or individuals for the purpose of scholarly research.

I further authorize Ryerson University to reproduce this MRP by photocopying or by other means, in total or in part, at the request of other institutions or individuals for the purpose of scholarly research.

I understand that my MRP may be made electronically available to the public.

Sheldon Funk 


\title{
COMMUNITY POLICING IN DURHAM REGION: IMPLICATIONS FOR DIVERSE ETHNIC GROUPS
}

\author{
Sheldon Funk \\ Master of Arts, 2014 \\ Immigration and Settlement Studies \\ Ryerson University
}

\begin{abstract}
Many academics have claimed that community policing has been unevenly applied, and that it is unable to address the needs of an ethnically diverse community. The goal is to assess if this assertion is true with respect to Durham Region. This study employs a document analysis of Durham Regional Police Service reports and the Government of Ontario's community policing orientation to determine whether its approach is representative of the provincial benchmark, and if it addresses ethnicized group concerns. The results suggest that community policing has been implemented with modest success in both regards.
\end{abstract}

Key words: community policing, diversity, police culture, communication 


\section{Acknowledgements}

I would like to thank Dr. Arne Kislenko for his invaluable contributions. He has provided me with advice, assistance, and encouragement over the past year as my course instructor, faculty advisor, and first reader. His open-mindedness was crucial in allowing me to pursue my research goals. Additionally, I would also like to acknowledge Dr. Anne Marie Singh for her deep involvement as the second reader. Much of this research could not have been accomplished without her expertise. 


\section{TABLE OF CONTENTS}

Introduction 1

Community Policing Concerns

Durham Region $\quad 3$

Structure

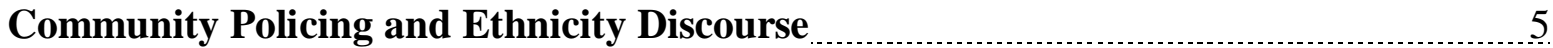

Origins

Dimensions

Community Policing in Canada $\quad 9$

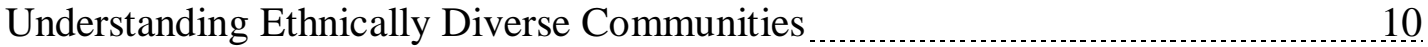

Police Community Relations $\quad 12$

Perceptions of Police

Stereotyping

Ethnic Issues and Community Policing Responses $\quad 20$

Aboriginals $\quad 2$

Recruitment $\quad 23$

Language and Culture $\ldots \ldots \ldots$

Muslims $\quad 26$

Method

Results

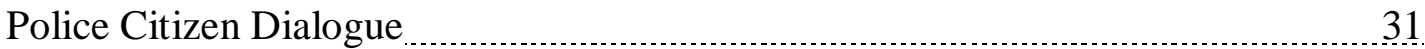

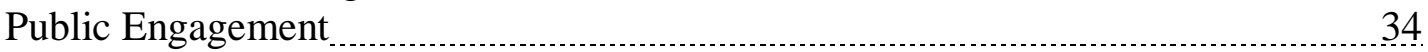

Language $\quad 37$

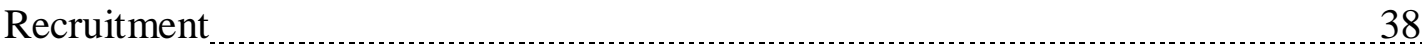

Partnerships $\quad 41$

Discussion $\quad 42$

Police Subculture

Cultural Sensitivity Training _ $\quad 43$

Conclusion $\quad 46$

Bibliography $\quad 48$ 


\section{INTRODUCTION}

Community policing is a law enforcement approach that has been used to connect police services with their respective communities. It has allowed police to be participative,

accountable, and integrative in a localized context. This initiative served as a replacement to the professional policing approach, which was more of a traditional and reactive form of crime control. ${ }^{1}$ The introduction of community policing also expanded upon Herman Goldstein's idea of problem-oriented-policing by addressing the whole panoply of community issues, rather than only focusing upon substantive problems. ${ }^{2}$ These developments in policing demonstrated an evolution of policing logic, and also showed an adaptation to the rapidly changing social, cultural, and economic demographics of Canada.

Even though it is not a new phenomenon, community policing continues to evolve over time. If policing protocols were able to shift from an aggressive professional policing orientation to community policing, then it is plausible that community policing may be replaced by another form of policing. This issue has been addressed by several subject matter experts in academic discourse. There is a concern that community policing is being ousted in favour of other models that reemphasize the need for security, and shift away from the "public" nature of policing. ${ }^{3}$ In doing so, the policing function is further separated from the community, and risks losing support amongst diverse ethnic groups by reverting to a more hierarchical and militarized method of crime control.

\footnotetext{
${ }^{1}$ Larry M. Coutts, Frank W. Schneider and Claudia Tenuta, "Recruiting Community Policing Officers: Reaching Out to a Broader Applicant Pool," Journal of Applied Social Psychology 34 (2004): 2629, accessed May 8, 2013. DOI: 10.1111/j.1559-1816.2004.tb01996.x.

${ }^{2}$ Gary Cordner and Elizabeth Perkins Biebel, "Problem Oriented Policing in Practice." Criminology and Public Policy 4 (2005): 160, accessed August 27 2013, DOI: 10.1111/j.1745-9133.2005.00013.x.

${ }^{3}$ Christopher Murphy, ““'Securitizing” Canadian Policing: A New Policing Paradigm For the Post 9/11 Security State?," The Canadian Journal of Sociology 32 (2007): 449, accessed May 8, 2013, DOI: $10.1353 /$ cjs.0.0022.
} 
This is a problem because one the main goals of community policing is to bridge the gap between the police and the public by fostering constructive two-way communication and participation. $^{4}$ If these opportunities are not provided, then the public would be limited in its ability to participate in policing initiatives and maintain a relationship with the police. In absence of such partnerships, the public would have to rely on the police to proactively address community related concerns with the assumption that the alternative policing orientation would accomplish this objective. It would not be plausible to assume that a local detachment could be responsive to a particular community's ethnic, linguistic, and cultural issues without any consultation. This demonstrates the importance of including the public, which the professional policing method neglected to do. For this reason, it would seem disconcerting that it has been losing favour.

Despite the concerns about community policing being phased out of police services, there is still an academic discourse which examines its use in practice. Several studies have indicated that there is a gap between the "rhetoric" and "realities" in community policing, ${ }^{5}$ and that it is unclear whether it is represented in policing policy and implemented by frontline officers in the field. ${ }^{6}$ Other academics challenge this view because they find that it incorrectly states that rhetoric and reality are "mutually exclusive" or in "binary opposition". 7 However, the concern about its presence has influenced the creation of this study which investigates the phenomenon in

\footnotetext{
" Jan Terpstra, "Governance and Accountability in Community Policing," Crime Law and Social Change 55 (2011): 88, accessed October 3, 2013, DOI: 10.1007/s10611-011-9272-y.

${ }^{5}$ Leighton N. Barry, "Visions of Community Policing: Rhetoric and Reality in Canada," Canadian Journal of Criminology 33 (1991): 485-522, accessed August 27, 2013, http://www.heinonline.org.ezproxy.lib.ryerson.ca/HOL/Page?page=485\&handle=hein.journals\%2Fcjccj33\&collecti on=journals.

${ }^{6}$ Allison T. Chappell, "The Philosophical Versus Actual Adoption of Community Policing," Criminal Justice Review 34 (2009): 5-28, accessed August 27, 2013, DOI: 10.1177/0734016808324244.

${ }^{7}$ Richard V. Ericson and Kevin D. Haggerty, Policing the Risk Society (Toronto: University of Toronto Press, 1997), 68.
} 
greater detail. The purpose is to examine the community policing orientation of a particular region, and compare it with the provincial benchmark.

In this case, the Durham Regional Police Service (DRPS) has been selected as the subject of study. Durham Region is a large territory which lies east of Toronto, and covers an area of 2,590 square kilometres. ${ }^{8}$ It currently hosts a population of 760,000 residents, and is projected to grow to 970,000 by 2021 , which is over double its population in 1991 . This demonstrates that Durham Region is growing quickly, and should continue to do so for the next decade. One of the primary reasons for choosing this area is that a plethora of studies have already examined the Toronto Police Service, and comparatively speaking, the DRPS has been neglected. Durham Region has not been subject to the same levels of ethnic diversification as Toronto, but its growth within the past two decades has significantly altered its racial, cultural, and linguistic composition. ${ }^{9}$ These changes will intensify the need for police to find ways to successfully interact with diverse ethnic groups.

However, the results from this study suggest that community policing has only been partially implemented in Durham Region. This has been largely due to distrust, language barriers, police subculture, community issues, and a lack of police-citizen dialogue. These themes are recurring throughout the literature review, the analysis, and the discussion.

Moreover, each section provides context to the community policing discourse as it applies to the police-public relationship. The body of this study begins with a discussion about the community policing discourse. This section explores how the term has been obfuscated, and why there is no universal definition. It also addresses the repeating claims about how community policing is

\footnotetext{
${ }^{8}$ Durham Region Planning Department, "Overview of Durham Region," accessed June 2, 2013, par. 1-3, http://www.durham.ca/default.asp?nr=/corpoverview/overview.htm\&setFooter=/includes/corpFooter.inc

${ }^{9}$ Durham Regional Planning Department, Durham Region Demographics: Social Characteristics (Whitby, ON: Durham Region, 2006), 1-9, http://www.durham.ca/departments/planed/planning/stats-nfacts/census/2006/charts/SocialCharacteristics.pdf
} 
being phased out in favour of other models. Furthermore, this section clarifies that the dividing lines between policing philosophies are not as distinct as they once were, and that police services often implement multiple approaches in tandem. The discussion concludes by discussing the moral, ethical, and procedural concerns of implementing a community policing strategy in an ethnically diverse environment. Essentially, it establishes a foundation of how the concept has been used, and will also lay the ground work for understanding the police-community relationship.

The first part of the literature review continues the discussion, but in the direction of police confidence measures. A recurring theme in this section is that ethnicized groups generally display poor confidence in the police. Although some of the studies that make these claims use research methods that retract from their legitimacy, they provide cause to investigate what influences these perceptions. The second half of the literature review is devoted to providing context to these issues, and delves into the community related problems that affect certain ethnic and religious groups in Canada. It exposes the need for community-oriented policing responses that are flexible to the public's concerns, which professional policing has struggled with in the past.

Following the conclusion of the literature review, this study returns to the discussion of the community policing approach. The method section introduces and qualifies documents that are used in the examination. Recurring themes from the literature review are also mentioned and their significance is explained. Lastly, it identifies and describes the document analysis method. This provides an understanding about its suitability and intended objectives. After the materials are examined in the analysis section, there is a general discussion of the findings. This allows for a series of observations to be drawn about how the current study compares to the literature. 
The discussion and conclusion sections also address the DRPS's partial implementation of community policing, and how it interacts with diverse ethnic groups. These conclusions are strongly influenced by how the community policing orientation is interpreted. Therefore, it is imperative that the discourse surrounding this concept be explored to provide context about how it is used by academics and police services.

\section{COMMUNITY POLICING AND ETHNICITY DISCOURSE}

Formative discourses of the community policing philosophy emerged in the 1960s and 1970s, albeit they were vastly different from modern interpretations. ${ }^{10}$ State welfarism was the prevailing school of thought, and reformist strategies were aimed at preventing the root causes of crime. Clients of community policing were assumed to be people in need of care, which reflected the treatment orientation of the state. These protection measures were imposed rather than formed in a cooperative agreement. ${ }^{11}$ Nonetheless, the approach was a preferred over previous social and enforcement related responses.

Even in the infancy stages of community policing, there were features that made it an attractive reformist model. It was viewed as a return to the founding principles of policing established by Sir Robert Peel, where the public are the police and the police are the public. ${ }^{12}$ This demonstrated a commitment to a relationship that encouraged mutual cooperation. The approach also utilized the community as a source of local knowledge and resources. ${ }^{13}$ Thus, the public was identified as "responsible community members" that were "partners", and acted as a "collective unit".

\footnotetext{
${ }^{10}$ Pat O’Malley and Darren Palmer, "Post-Keynesian Policing," Economy and Society 25 (1996): 138, accessed October 13, 2013, DOI: 10.1080/03085149600000007.

${ }^{11}$ O’Malley and Palmer, "Post-Keynesian Policing," 138.

12 Ibid., 144.

${ }^{13}$ Ibid., 145-148.
} 
One of the main concerns with community policing is how it is conceptualized in literature. There is an abundance of scholarship stating that it is "modern", "progressive", "contemporary", "clientelistic", and "partnership oriented". 14 Many of the definitions offered by academics are also conceptually ambiguous because they state general guidelines without thoroughly explaining the material. ${ }^{15}$ Sutham Cheuprakobit was particularly critical of these ambiguous interpretations because he found that they produced contradistinct notions of community policing. ${ }^{16}$ This has led some academics to separate their definitions of community policing based on the context in which it is used.

William Rohe, Richard Adams, and Thomas Arcury argued that it can be divided into three tiers, which include the philosophical level, the program level, and the activity level. ${ }^{17}$ Their rationale behind this separation is that community policing is viewed differently in each of the three dimensions. It was explained in their article that the philosophical level emphasizes a shared responsibility between the police and the public. This is maintained through constant communication and joint police-public crime prevention responses to the social antecedents of crime. Contrarily, the authors found that there is no ubiquitous orientation at the program and activity levels because each police department uses their own discretion to create programs that are dedicated to responding to social and economic conditions of localities. For instance, cities such as Ottawa and Winnipeg have vastly different budgets, demographics, and crime levels, which ultimately affect their ability to implement community policing.

\footnotetext{
${ }^{14}$ Leighton, "Visions of Community Policing," 485.

${ }^{15}$ Edward Macguire and Stephen Mastrofski, "Patterns of Community Policing in the United States," Police Quarterly 3 (2000): 5-8, accessed August 7, 2013, DOI: 10.1177/1098611100003001001.

${ }^{16}$ Sutham Cheuprakobit, “Community Policing: Training, Definitions, and Policy Implications," Policing: An International Journal of Police Strategies \& Management 25 (2002): 712, accessed September 1, 2013, DOI: 10.1108/13639510210450640.

${ }^{17}$ William M. Rohe, Richard E. Adams and Thomas A. Arcury, "Community Policing and Planning," Journal of the American Planning Association 67 (2001): 78-79, accessed June 10, 2013, http://search.proquest.com.ezproxy.lib.ryerson.ca/docview/229642456.
} 
When considering how important geography is in the study of community policing, there are a number of scholars that neglected to account for this aspect. Matthew Scheider, Robert Chapman, and Amy Schapiro's argument stated that territorial differences affect the implementation of community policing. ${ }^{18}$ They continued by mentioning that solutions to local problems must be created at the local level. The authors also purported that the community policing definition should not become too specialized because it needs to account for a wide range of responses. In this case, the ambiguous nature of the term enables police services to be creative.

Other academics argued that institutional interest in the concept will lead to a dearth of flexible responses. Edward Macguire and Stephen Mastrofski found that institutions were more concerned with the legitimacy of community policing rather than its technical aspects. ${ }^{19}$ They argued that this will lead police departments from a multidimensional to a one-dimensional format. However, Macguire and Mastrofski were unable to definitively test for this transition, which makes it difficult verify their claims. On the other hand, scholars such as Christopher Murphy blamed the institutional "securitization" of police services for the shift towards rigid hierarchical policing. ${ }^{20}$ His rationale is that intelligence-led-policing has replaced community policing in the post 9/11 era. The problem is that Murphy's argument is an overly simplistic summarization of policing developments and an ill-conceived understanding that police services use one approach in exclusivity.

There is greater evidence to suggest that the community policing orientation is an amalgam of multiple policing methods. John Murray stated that this can be an effective

\footnotetext{
${ }^{18}$ Matthew C. Scheider, Robert Chapman, and Amy Schapiro, "Towards the Unification of Policing Innovations under Community Policing," Policing: An International Journal of Police Strategies \& Management 32 (2009): 696, accessed September 3, 2013, DOI: 10.1108/13639510911000777.

${ }^{19}$ Macguire and Mastrofski, "Patterns of Community Policing in the United States," 15.

${ }^{20}$ Murphy, ““'Securitizing” Canadian Policing,” 459-468.
} 
approach if police services operate under the community policing label. ${ }^{21}$ This is appears to be the trend for many agencies in Canada. The Ontario Association of Chiefs of Police's (OACP) Community Mobilization and Engagement Model contains a layered approach, which suggests the use of community consultation and public led responses in low crime zones, and enforcement policing and community intelligence gathering in high crime zones. ${ }^{22}$ Moreover, the reason why many Canadian police agencies adopted the model shares no likeness with the "securitization" hypothesis.

The transition from professional policing to community policing in Canada was influenced by the policing administration's interest in emulating a business model. In 1990, the release of the Police Challenge 2000: A Vision of the Future of Policing in Canada paper by Federal Solicitor General Pierre Cadieux placed a significant amount of pressure on the Royal Canadian Mounted Police (RCMP) to structurally shift its organization. ${ }^{23}$ The document contained technocratic and business oriented phrases such as "empowerment", "core values", "total quality", "user pay systems", and "excellence risk taking". Furthermore, the release of the document influenced the RCMP to make large budgetary cuts, which included a sizeable reduction of its uniformed staff. Converting to a business model also meant offloading many of the costs and responsibilities of the police onto the community. An RCMP superintendent stated that the "...trend has been to get the community to do things that the police have traditionally been doing. If it is a priority to the community and goes beyond the core development of

\footnotetext{
${ }^{21}$ John Murray, "Policing Terrorism: A Threat to Community Policing or Just a Shift in Priorities?," Police Practice and Research 6 (2005): 348, accessed May 11, 213, DOI: 10.1080/15614260500293986.

${ }^{22}$ Ontario Association of Chiefs of Police, "Preparing for a Safer Community: Ontario's New Community Policing Model," Wilfrid Laurier University website, accessed September 3, 2013, 24, http://www.wlu.ca/documents/45682/Ontario_Community_Policing_Model_NEW.pdf.

${ }^{23}$ Curtis A. Clarke, "Between a Rock and a Hard Place: RCMP Organizational Change," Policing: An International Journal of Police Strategies \& Management 25 (2002): 15, accessed October 5, 2013, DOI: $10.1108 / 13639510210417872$.
} 
policing, as set out in the Provincial and Municipal contracts, then the community must come up with the resources. ${ }^{24}$ This type of restructuring also affected other police services across Canada.

In the Greater Toronto Area, there was a significant amount of pressure for municipal restructuring, which included accounting improvements and greater interdepartmental information sharing. ${ }^{25}$ It also proposed a shift from bureaucratic control to innovative managerialism. This had profound effects on police services in the area. Horizontal forms of accountability enhanced the accountability structure, and bridged the relationship between the police and the community. ${ }^{26}$ The outcome of this drastic shift fundamentally altered service delivery models of police agencies within the area. Nonetheless, a primary concern from the policing administration is that it remains responsive to the complex social issues of urban areas. ${ }^{27}$

As policing modalities continue to develop, the communities that they serve will also change in size and composition. It is important to consider that many of them will continue to diversify due to the influx of new immigrants and decreasing birth rate among native born Canadians. ${ }^{28}$ Immigration continues to play a central role in the ethnic diversification of Canada's largest cities, which demonstrates the need to understand who and what constitute a community. Daniel Flynn stated that most police services define the term "community" based on jurisdiction. ${ }^{29} \mathrm{He}$ argued that individual and organizational stakeholders often do not reside

\footnotetext{
${ }^{24}$ Clarke, "Between a Rock and a Hard Place," 18.

${ }^{25}$ Curtis A. Clarke, "Hands Firmly on the Steering Wheel: Restructuring Metro Toronto Police Service," Policing: An International Journal of Police Strategies \& Management 26 (2003) 474-477, accessed October 8, 2013, DOI: 10.1108/13639510310489502.

${ }^{26}$ Terpstra, "Governance and Accountability in Community Policing," 88.

${ }^{27}$ Clarke, "Hands Firmly on the Steering Wheel," 474.

${ }^{28}$ Phillip C. Stenning, "Policing the Cultural Kaleidoscope: Recent Canadian Experience," Police and Society 7 (2003): 14-15.

${ }^{29}$ Police Executive Research Forum, Defining the "Community" in Community Policing, by Daniel W. Flynn (Washington, DC: Police Executive Research Forum, 1998), 4, http://www.policeforum.org/library/community-policing/cp.pdf.
} 
within these districts, and that this may cause the police to engage in partnerships with incomplete groups. Some police services have modified their mandates to account for this issue. For example, the OACP stated that the community "includes every person or organization that is affected by any real or anticipated threat to peace, security and well being. ${ }^{30}$ This signifies a development in the understanding of community because it gives greater consideration to the people who frequent the region rather than purely emphasizing the geographic unit.

Therefore, it is especially important to understand the groups that reside within them. Although there are a variety of terms to describe Canada's heterogeneous communities, there are embedded flaws and limitations that contribute to their inherent complexity. ${ }^{31}$ This is partly due to the dynamic, ambiguous, and shifting nature of these descriptors. An argument can be made that the complications of these terminologies resemble those that affect the community policing definition. The amorphous and broad nature of these definitions appears to be necessitated, but also inhibits the distinctions made within each category of race, ethnicity, religion, creed, and culture. These issues were reflected in the work of Ien Ang where it was mentioned that;

After many generations of immigration history, migrants and their descendants are no longer containable within a fixed and internally homogeneous category of "ethnic community," as tended to be assumed in the formative years of state-sponsored multiculturalism. Witness the second, third, and fourth generations, whose ethnic identities are increasingly fluid, hybridized and Westernized. Nor has there been a smooth process of integration of migrants into the national community, not because multiculturalism encouraged them to lead parallel lives, but because differences between people(s) - racial, cultural, religious - are very resistant to erasure: processes of inclusion and exclusion, the differentiation of the self and other, and the drawing of dividing lines between us and them are an enduring feature of the human way of life. ${ }^{32}$

\footnotetext{
${ }^{30}$ Ontario Association of Chiefs of Police, "Preparing for a Safer Community," 23.

${ }^{31}$ Barbra Perry, "Policing Hate Crime in a Multicultural Society: Observations from Canada," International Journal of Law, Crime and Justice 38 (2010): 122, accessed October 5, 2013, DOI: 10.1016/j.ijlcj.2010.10.004.

${ }^{32}$ Augie Fleras, ““'From Mosaic to Multiversality”: Repriming Multicultural Governance in a Postnational Canada," Canadian Ethnic Studies 43 (2011): 19, accessed October 8, 2013, DOI: 10.1353/ces.2011.0004.
} 
Consequently, this shows that creating multicultural policy is particularly onerous. These policies can be argued as being both inclusive and divisive, and are largely subject to how they are interpreted. It can be argued as being divisive because it emphasizes individual racial, ethnic, cultural, and religious identities. Conversely, it can also be argued as being inclusive. Augie Fleras purported that multicultural policy emphasizes bounded ethnic identities within a papered framework, which promotes national unity. ${ }^{33}$ This demonstrates the complexity of addressing it in policy. There are also a variety of moral obstacles that complicate criminal investigations.

Canadian police services have been tasked with enforcing both criminal law and cultural protection law. The competing influences of these two legislative frameworks places frontline officers in a difficult situation. For instance, drawing the line between free speech and hate speech can be an ethical dilemma. Aggressively policing speech may appear to be infringing upon the civil liberties of one group, while the neglect of victims may be perceived as abandonment. The answer to this problem is not one that is easily arrived at. Several studies from the literature suggested that the police are not only neglectful in policing certain regions, but also exercise their own prejudicial attitudes toward ethnicized groups. Some of them are also critical of community policing, and find that it falls short of its objectives. This is a recurring issue, but other authors have argued that the public strongly supports community policing initiatives.

\footnotetext{
${ }^{33}$ Fleras, ““'From Mosaic to Multiversality”," 20.
} 


\section{POLICE-COMMUNITY RELATIONS}

For instance, Don Clairmont found that community policing generally had a positive impact on the community and the perceptions citizens had of the police. ${ }^{34}$ Clairmont further added that the police and community managed to foster a greater working relationship by implementing community policing initiatives. However, he found that most police services stated their community policing objectives without any assessment tools in place to determine if it was reflected in policy and practice. A major concern with Clairmont's study is that he neglected to account for representativeness of community support. Other questions could have been asked in order to understand how much community policing was supported across different groups. If support for policing in general were to be looked at more broadly, and in the context of ethnicized group support, then the research appears to show a mixed record.

A study conducted by Donald Walker and Peter Kratcoski cited results contrary to Clairmont's. These findings suggested that the overall support for police in Toronto was rather low. Only $36 \%$ of respondents rated police-citizen relations as good, while $60 \%$ of participants provided ratings in the fair and poor categories. ${ }^{35}$ The article also discussed results from another research project, and when compared to the other study, there were dissimilarities about support for police in Toronto. One of the main weaknesses of this article is that respondent demographics were not accounted for, nor were the measurements for sampling. This appears to be the trend for most of the earlier studies about public perceptions of the police. The amount of

\footnotetext{
${ }^{34}$ Don Clairmont, "Community Based Policing: Implementation and Impact," Canadian Journal of Criminology 33 (1991): 472, accessed May 10, 2013, http://www.heinonline.org.ezproxy.lib.ryerson.ca/HOL/Page?page=469\&handle=hein.journals\%2Fcjccj33\&collecti on=journals

${ }^{35}$ Peter B. Walker and Peter C. Kratcoski, "Cross Cultural Perspective on Police Values and PoliceCommunity Relations," Criminal Justice Review 10 (1985): 19, accessed May 8, 2013, DOI: $10.1177 / 073401688501000103$.
} 
Canadian based literature in this field is still limited, but some studies have broached the subject of perceptions of police.

Scot Wortley and Akwasi Owusu-Bempah analyzed White, Black, and Chinese respondent perceptions of the police and courts. Their study was built off of previous inconsistent findings from Europe and the United States about ethnicized group perceptions of police. The researchers found that Whites evaluated police performance the strongest, followed by Blacks, and lastly Chinese. ${ }^{36}$ Wortley and Owusu-Bempah were also able to make determinations about the effect that immigration had on the public's perceptions of the police. Those who were newer immigrants were less likely to perceive police bias than established immigrants and native born Canadians. ${ }^{37}$ The authors also provided a summary of what each ethnic group as a whole perceived of police bias. Black and Chinese respondents reported that their own racial groups received greater police bias than Whites, but when asked about the other group's experiences relative to Whites, both Black and Chinese respondents understated the presence of police bias. ${ }^{38}$ Thus, the results of the study provided evidence that the respondents' subjective experiences may have influenced their answers. There are still questions that need to be answered such as why these experiences affected the participants' responses. It would have also been useful to have implemented some form of measurement in determining whether the number of encounters that respondents had with police affected their decision-making. However, an egregious error within this study is its poorly conceived notion of racial classification.

\footnotetext{
${ }^{36}$ Scot Wortley and Akwasi Owusu-Bempah, "Unequal Before the Law: Immigrant and Racial Minority Perceptions of the Canadian Criminal Justice System," International Migration and Integration 10 (2009): 456, accessed May 24, 2013, DOI: 10.1007/s12134-009-0108-x.

${ }^{37}$ Wortley and Owusu-Bempah, "Unequal Before the Law," 457.

${ }^{38}$ Ibid., 458.
} 
At no point during the article did the authors critically engage with this arbitrary labelling of the respondents' race. Wortley and Owusu-Bempah attempted to justify their classification method by stating that they were replicating a 1994 survey conducted by the York University's Institute for Social Research, but this neglected to address the problem inherent in the methodology. These racial classifications are incredibly large catch basins, and can include a large number of nationalities, ethnicities, and creeds. Two of these categories are loosely understood skin colours, while the term "Chinese" carries ethnic, national, and linguistic connotations. There is also the issue of interethnic mixing, and making determinations about which group each respondent is meant to be classified under. Wortley and Owusu-Bempah did not account for respondents of an ethnically mixed background, nor did they account for groups that were excluded as a result of this rigid classification. Some of the other studies were more thorough and included demographic characteristics in their analyses.

Christopher O’Connor examined police perceptions more generally across racialized communities. ${ }^{39}$ His results were consistent with prior studies, but he was able to offer more to the discussion. A resounding criticism in the literature about police-confidence studies was that most of the researchers neglected to include respondent demographic variables. ${ }^{40}$ O'Connor addressed that gap by examining a variety of participant characteristics, and he made a series of observations. Respondents reported poor satisfaction with police if they were young, from an ethnicized group, had high levels of crime in their community, held concerns about their safety, and had been previously victimized. ${ }^{41}$ While he was able to contribute conclusions about

\footnotetext{
${ }^{39}$ Christopher O'Connor, "Citizen Attitudes towards the Police in Canada," Policing: An International Journal of Police Strategies \& Management 31 (2008): 578-595, accessed May 8 2013, DOI: 10.1108/13639510810910571.

${ }^{40}$ Liqun Cao, "Visible Minorities and Confidence in the Police," Canadian Journal of Criminology and Justice 53 (2011): 14, accessed May 8, 2013, DOI: 10.1353/ccj.2011.0014

${ }^{41}$ O'Connor, "Citizen Attitudes towards the Police in Canada," 590.
} 
demographic characteristics to the discussion, there were background circumstances that lacked explanation. O'Connor identified variables such as "visible minority" as determinants of police satisfaction, but did not explain their significance. ${ }^{42}$

Building off the groundwork of O'Connor's study, Liqun Cao researched the intersection of demographic characteristics and ethnicized group confidence in the police. The results demonstrated stronger confidence levels than in O'Connor's article. When compared to Canadian born citizens, the statistics showed similar results in the strong support category. Cao inquired about variables such as confidence in the police enforcing the law, being approachable, and ensuring the safety of citizens. ${ }^{43}$ He was able to determine that the variables had been affected by the respondents' gender, age, education, and marital status. Cao concluded that those who were older, female, and married were more likely to express strong confidence levels in police than were racialized young men that were single. What this shows is that the article extended beyond the parameters of O'Connor's study by accounting for external factors that influenced the respondents' answers.

Of paramount concern is how these results will be understood and generalized in the field of ethnicized group perceptions of the police. As mentioned earlier, Canada is an ethnically, religiously, and culturally diverse country. It is important to consider the geographic dispersion of these diverse ethnic groups, and that there are considerable compositional differences in Canadian cities. The configuration of these cities is subject to change over time due to the fluid nature of Canada's increasingly diverse society. This is a primary reason why Cao's reliance on the 1999 General Social Survey limited the applicability of the results. ${ }^{44}$ It is important to use recent data to account for this change, but in Cao's study, the data was already 13 years old at the

\footnotetext{
${ }^{42}$ Cao, "Visible Minorities and Confidence in the Police," 5.

${ }^{43}$ Ibid., 11-14.

${ }^{44}$ Ibid., 5 .
} 
time of its creation. This draws into question whether the information was reflective of Canada's population demographics. However, in the broader scope of the study about the public's perception of the police, there are trends worth examining.

Most of the literature purported that racialized communities displayed poor levels of confidence in the police. This provides cause to conduct follow-up research by investigating why these ethnicized groups are aggrieved by Canadian police services. These reasons may be particularly beneficial to the policing administration because it would allow them to address the issues through problem-oriented-policing. Additionally, these findings may also influence academics to engage in comparative studies to see if there are regional differences in perceptions of the police. If there is a strong variation in ethnic group support by jurisdiction, then it may influence greater information sharing between police services in order to identify the best practices for maintaining public support.

Conversely, some scholars have stated that there are limitations of what these studies are capable of accomplishing. Phillip Stenning mentioned that there is an abundance of research with anecdotal evidence of police discrimination, and that there is an absence of "hard" data to support any of these personalized claims. ${ }^{45}$ He also purported that research with the purpose of acquiring race-based data has been viewed as a contentious issue. The rationale behind his argument is that it has been steadfastly resisted in Canada out of fear that the results may be particularly damaging to specific racialized communities. On the contrary, it is disputable that making such distinctions will somehow be beneficial. Stenning failed to explain why this is necessary in criminological research. He stated that other academics were skeptical about the usefulness and accuracy of collecting this type of data, but fell short of explaining why. When

\footnotetext{
${ }^{45}$ Stenning, "Policing the Cultural Kaleidoscope," 32.
} 
considering the complexities of differentiating individuals by race, there is a concern that biases and discriminatory behaviours may undermine these efforts.

Racial profiling delegitimizes advancements made in policing initiatives. Many racialized communities take offence to this practice since it can be used to unjustly and systemically target specific groups. Of particular concern to many racialized communities are the attitudes and behaviours of the police. Guy Ben-Porat mentioned that the legitimacy and credibility of Canadian police services has yet to be fully accepted, and this is largely attributable to racial profiling. ${ }^{46}$ The notion of its existence in Canada has been described by some as incontrovertible, but several scholars have struggled to legitimate these claims due to weaknesses within their methodologies.

Notably, the Toronto Star conducted its own independent investigation into police treatment of Black Torontonians. ${ }^{47}$ The study found that Blacks were overrepresented in certain types of charges, and that they received poorer treatment than White offenders. Public discussions interpreted the article's findings as evidence of maltreatment. ${ }^{48}$ One of the main issues with the newspaper article is that, in academia, its method was viewed as controversial. Ron Melchers criticized the findings from the Toronto Star by pointing out flaws within its methodology. Most importantly, he highlighted that the report did not possess race-based data,

\footnotetext{
${ }^{46}$ Ben-Porat, Guy, "Policing Multicultural States: Lessons from the Canadian Model," Policing and Society 18 (2008): 412, accessed May 24, 2013, DOI: 10.1080/10439460802094686.

47 Jim Rankin, Jennifer Quinn, Michelle Shephard, Scott Simmie and John Duncanson. "Singled Out," Toronto Star, October 19, 2002, accessed June 11, 2013, http://www.thestar.com/news/gta/knowntopolice/singledout.html

${ }^{48}$ Vic Satzewich and William Shaffir, "Racism versus Professionalism: Claims and Counter-claims about Racial Profiling," Canadian Journal of Criminology and Justice 51 (2009): 202, accessed June 11, 2013, DOI: 10.1353/ccj.0.0053.
} 
and attempted to cross-match it with 1996 Census findings under the assumption that the Census statistics would represent Toronto's ethnicized group composition. ${ }^{49}$

Scot Wortley and Julian Tanner also explored the issue of racial profiling of Black Canadians. The purpose of this study was to identify how many times respondents were part of police traffic stops. They concluded that Black respondents were stopped the most, followed by Whites, West Asians, Asians, and lastly, South Asians. ${ }^{50}$ This was true even when controlling for other variables such as delinquency. Wortley and Tanner accounted for 23 different criminal offences, and the results suggested that these factors carried no effect on whether a Black respondent was stopped by the police. In a follow-up study, the authors conceded that crude racial distinctions in Canadian racial profiling studies have undermined the quality and legitimacy of their results. ${ }^{51}$ This was one of the few studies in the literature that gave consideration to the arbitrary labelling of respondents.

Thomas Gabor was particularly critical of the methods that Wortley and Tanner employed in their original article Data, Denials, and Confusion: The Racial Profiling Debate in Toronto. He argued that their conceptualization of racial profiling was erred in its design, and neglected to account for the difference between bigotry and police operations in high priority communities with the intent of disrupting crime networks, identifying crime patterns, and collecting intelligence. ${ }^{52}$ Furthermore, Gabor pointed to the paradoxical dilemma of policing

${ }^{49}$ Ron Melchers, "Do Toronto Police Engage in Police-profiling?," Canadian Journal of Criminology and Justice 45 (2003): 350-352, accessed June 11, 2013, http://search.proquest.com.ezproxy.lib.ryerson.ca/docview/216107956

${ }^{50}$ Scot Wortley and Julian Tanner, Data, Denials, and Confusion: The Racial Profiling Debate in Toronto, Canadian Journal of Criminology and Justice 45 (2003): 367-369, accessed May 24, 2013, http://search.proquest.com.ezproxy.lib.ryerson.ca/docview/216094986\#.

${ }^{51}$ Scot Wortley and Julian Tanner, "Inflammatory Rhetoric? Baseless Accusations? A Response to Gabor's Critique of Racial Profiling Research in Canada," Canadian Journal of Criminology and Justice 47 (2005): 581-609, accessed May 24, 2013, http://search.proquest.com.ezproxy.lib.ryerson.ca/docview/216104601.

52 Thomas Gabor, "Inflammatory Rhetoric on Police-profiling Can Undermine Police Services," Canadian Journal of Criminology and Justice 46 (2004): 458-60, accessed May 24, 2013, 
high priority communities by mentioning that it creates a no-win situation. He was referring to the repeating claims of over and under-policing, and that police will inevitably be scapegoats for making the wrong choice. Gabor also stated that the perception of profiling is not an objective measure of its existence, and that the authors did not have a verifiable tool to distinguish between legitimate and illegitimate policing. For instance, were all cases across ethnic groups assumed to be racial profiling, or only those within the Black category?

Vic Satzewich and William Shaffir took a different route when they inquired about racial profiling by conducting a series of interviews with police constables from the Hamilton Police Service. ${ }^{53}$ The officers were questioned about its presence amongst the uniformed ranks. Many of the respondents mentioned during their interviews that in policing, race is not a standalone feature, and it is part of a much larger process of general criminal profiling. One of the problems is that in high priority areas, the use of profiling can overemphasize race and be implemented systemically across the region. ${ }^{54}$ These deviations in profiling practices are sometimes related to a phenomenon known as "police subculture". It can be succinctly described as an ideology that promotes likeminded beliefs about how police work should be exercised and how to approach the kind of people with whom police typically interact with. ${ }^{55}$ The problem with police subculture is that police services are often in denial about its existence, and the culture itself is not rooted in a few select cases, but more widespread where entire groups or departmental philosophies are affected. ${ }^{56}$ Satzewich and Shaffir were able to shed light on how pervasive

http://web.ebscohost.com.ezproxy.lib.ryerson.ca/ehost/pdfviewer/pdfviewer?sid=ea115eae-4b13-46cd-857ecdb7be99fee 8\%40sessionmgr104\&vid=2\&hid $=125$

${ }^{53}$ Satzewich and Shaffir, "Racism versus Professionalism," 199-226.

${ }^{54}$ Ibid., 209-211.

${ }^{55}$ Ibid., 208.

${ }^{56}$ Ibid., 201. 
racial profiling can be, and even documented that several Hamilton police officers believed that it was evident within their own department.

Irrespective of the racial profiling debate, there must be strategies in place to reduce the perceptions of unfair and unjust actions of the police. It is especially important to ensure that racialized communities support Canada's police services because one of the primary principles of policing is that it maintains popular support of the public. ${ }^{57}$ In this case, it should be a priority for police services to establish trust and support from diverse ethnic groups, and not let the issue exacerbate existing tensions. The community policing definition directly states that there needs to be proactive community initiatives to foster a positive working relationship. Under the auspices of reducing crime, police services should identify social issues rather than developing character profiles that are formed solely on the basis of race. This would ensure that problems are understood as a regional issue rather than one ascribed to a certain ethnic group.

\section{ETHNIC ISSUES AND COMMUNITY POLICING RESPONSES}

It is also necessary to comprehend the issues of each ethnic community, and to have policing policy address those matters. ${ }^{58}$ This highlights the priorities for the specific police detachment, and allows them to focus on the background characteristics that lead to crime. Focusing on social problems provides police with the opportunity to be proactive and engage with the community rather than limiting their resources to reactive crime responses. Before police services partake in the problem solving method, there should be some level of discussion about the specific social issues of Canada's diverse ethnic communities.

\footnotetext{
${ }^{57}$ Rowe, "Policing Diversity," 439.

${ }^{58}$ Yuning Wu, Ivan Y. Sun and Brad W. Smith, “Race, Immigration, and Policing: Chinese Immigrants' Satisfaction with Police," Justice Quarterly 28 (2011): 770, accessed May 16, 2013, DOI: 10.1080/07418825.2010.535009
} 
Consider the experiences of Aboriginal peoples. Even though they are linguistically, culturally, and socially different from one another, there are contemporary social issues that are more broadly applicable. Wanda McCaslin and Yvonne Boyer stated that Aboriginal communities have weak social welfare programs, which struggle to support those in need of assistance. ${ }^{59}$ This is especially true regarding youth who are affected by health problems, inadequate housing, and difficulties within the educational system. While there may be trends that affect the Aboriginal groups across Canada, some regions are affected more than others. Understanding the differences of community profiles is important when developing policing approaches. For instance, the rate of violent crime on reserves is significantly higher than in urban areas, ${ }^{60}$ but violent crime amongst Aboriginal peoples is still part of a broader trend. Mia Dauvergne and Geoffrey Li reported that Aboriginal youth are overrepresented in homicide cases, and in 2005, they represented $23 \%$ of all persons accused of homicide. ${ }^{61}$

This should not underscore the fact that those who live in urban areas face a plethora of different issues. Many of them are living in Census Metropolitan Areas such as Toronto, Montreal, and Vancouver. ${ }^{62}$ One of the main problems affecting urban Aboriginal peoples is that they tend to be more mobile than other ethnicized groups and disconnected from their own community. There are also considerable differences in the quality of livelihood that they are able to attain within cities. Aboriginal peoples in Canada's largest metropolitan areas have been

\footnotetext{
${ }^{59}$ Wanda D. McCaslin And Yvonne Boyer, "First Nations Communities at Risk and in Crisis: Justice and Security," Journal of Aboriginal Health 5 (2009): 69-70, accessed May 24, 2013, http://www.naho.ca/documents/journal/jah05_02/05_02_03_Communities.pdf

${ }^{60}$ Savvas Lithopolous and Rick Ruddell, "Policing Isolated Aboriginal Communities: Perspectives of Canadian Officers," Policing: An International Journal of Police Strategies \& Management 34 (2011): 434-453, accessed May 21, 2013, DOI: 10.1108/13639511111157500.

${ }^{61}$ Mia Dauvergne and Geoffrey Li, "Homicide in Canada, 2005." Juristat: Canadian Centre for Justice Statistics 26 (2006): 1-25, accessed October 5, 2013, http://search.proquest.com.ezproxy.lib.ryerson.ca/docview/216180255.

62 Jane Dickson-Gilmore, "Aboriginal Communities and Crime Prevention: Confronting the Challenges of Organized Crime,” IPC Review 1 (2007): 94-95, accessed June 2, 2013. http://www.sciencessociales.uottawa.ca/ipc/pdf/kr4-dickson-gilmore.pdf.
} 
successful in integrating into the economy. ${ }^{63}$ However, those who reside in cities such as Edmonton, Winnipeg, and Thunder Bay are known to be the youngest, undereducated, poorest, least employed, and most mobile of all Aboriginal peoples in Canada. This shows that there are considerable differences across metropolitan areas. Moreover, geography is one of the central issues that has framed their negative experiences in Canada, and is historically rooted in grievances with respect to land access.

There has been a longstanding feud between Aboriginal peoples and the Canadian government about land ownership. This struggle exists through political, legal, extra-legal, and other means to legitimate their claims to certain lands. ${ }^{64}$ The issue is that the police are considered an extension of the government's use of authority, and have often been placed at the forefront of this politicized struggle. These standoffs can perpetuate a vicious cycle of negative interactions between the police and Aboriginal peoples, and have been one of the main points of contention. Historical narratives of this relationship have described the police as being repressive, and that they have used containment and confinement strategies when dealing with Aboriginal peoples. ${ }^{65}$ Similarly, the formative discourses of policing in Canada have questioned whether it is resemblant of democratic principles.

Some scholars have argued that policing has not been consensus based. This is disconcerting when considering what constitutes effective policing. The Ipperwash Inquiry reiterated principles from the Patten Report where it was stated that democratic policing is

\footnotetext{
${ }^{63}$ Dickson-Gilmore, "Aboriginal Communities and Crime Prevention," 94-95.

${ }^{64}$ Ben-Porat, Guy, "Policing Multicultural States: Lessons from the Canadian Model," Policing and Society 18 (2008): 417, accessed May 24, 2013, DOI: 10.1080/10439460802094686..

${ }^{65}$ Amanada Nettelbeck and Russell Smandych, "Policing Indigenous People on Two Colonial Frontiers: Australia's Mounted Police and Canada's North West Mounted Police," The Australia and New Zealand Journal of Criminology 43 (2010): 356-370, accessed December 12, 2013, http://go.galegroup.com.ezproxy.lib.ryerson.ca/ps/i.do?action=interpret\&id=GALE\%7CA237838149\&v=2.1\&u=rp u_main\&it=r\&p=AONE\&sw=w\&authCount $=1$.
} 
dependent upon consent across the community. ${ }^{66}$ It also concluded that police services must be representative of the communities that they serve. ${ }^{67}$ Several strategies were outlined in the inquiry, which emphasized the inclusion of racialized communities. This included steps such as supporting diversity policy and engaging in proactive recruitment. In theory, it was supposed to alter the ethnic composition of Canadian police services, but academics have been pessimistic about the efforts to acquire diverse ethnic recruits. There is a resounding criticism in the literature that the Canada-wide effort to integrate racialized communities into policing has yielded poor results. ${ }^{68}$ Contrastingly, some studies have investigated methods to remedy this issue.

Larry Coutts, Frank Schneider, and Claudia Tenuta assessed how the police can reach out to a broader applicant pool. They surveyed a group of participants and received 590 statements in return, and the responses represented an array of different topics in policing. What they found in their study is that the majority of respondents associated policing with the professional policing format. ${ }^{69}$ The participants also indicated that they preferred community policing over professional policing, but this was only true after the authors had informed them about the changes in community policing. A major issue with the article is that Coutts, Schneider, and Tenuta did not define community policing, nor did they mention how this concept was explained to the participants. They played a significant role in shaping the respondents' opinions about

\footnotetext{
${ }^{66}$ Ipperwash Inquiry, Discussion Paper on Police/Government Relations, by Nye Thomas (Toronto, ON: Ministry of the Attorney General, 2006, 3), http://www.attorneygeneral.jus.gov.on.ca/inquiries/ipperwash/policy_part/discussion/pdf/IpperwashPolicingOccupat ions_DiscussionPaper_June2006.pdf.

${ }^{67}$ Ipperwash Inquiry, Discussion Paper on Policing Occupations and Police Aboriginal Relations, by Nye Thomas (Toronto, ON: Ministry of the Attorney General, 2006, 18), http://www.attorneygeneral.jus.gov.on.ca/inquiries/ipperwash/policy_part/discussion/pdf/IpperwashPolicingOccupat ions_DiscussionPaper_June2006.pdf.

${ }^{68}$ Harish C. Jain, Parbduyal Singh and Carol Agocs, "Recruitment, Selection and Promotion of Visible-minority and Aboriginal Police Officers in Selected Canadian Police Services," Canadian Public Administration 42 (2000): 46-67, accessed May 12, 2013, DOI: 10.1111/j.1754-7121.2000.tb01560.x.

${ }^{69}$ Coutts, Schneider and Tenuta, "Recruiting Community Policing Officers", 2635-2638.
} 
policing, but did not discuss the possibility that the "interviewer effect" may have interfered with their results. When examining the literature more thoroughly, it is evident that there are other factors that impede ethnicized group inclusion. One of the labyrinthine issues that policing policy must address is the language and culture of racialized communities.

Doris Chu and John Huey-Long Song broached this subject by measuring Chinese Torontonian perceptions of police practices. While the study was related to "opinions" about policing, the results are relevant in terms of a discussion regarding ethnic group concerns. What the authors found in their study is that respondents had mixed feelings about the police. They provided constructive criticism about how police services could foster better interaction with diverse ethnic groups. ${ }^{70}$ The participants stated that the greatest problem affecting the police's relationship with the Chinese community was language. They purported that their poor English skills inhibited their ability to communicate with the police. One of the other issues mentioned in the interviews was the differences in the culture of communication. The participants felt that the police needed to understand Chinese cultural backgrounds in order to successfully communicate with them. ${ }^{71}$ However, the results from this article were inapplicable. Chu and Song acknowledged that their findings could not be generalized due to the fact that they used non-probability sampling. ${ }^{72}$ The participants were recruited from community service centres, which showed that the authors only consulted a very small portion of Chinese Torontonians. Nonetheless, the authors were successful in identifying that language barriers were not the only issue that hindered police-public communication, but that cultural barriers in communication also impeded their interaction.

7070 Doris Chu and John Huey-Long Song, “Chinese Immigrants' Perceptions of the Police in Toronto, Canada," Policing: An International Journal of Police Strategies \& Management 31 (2008): 623, accessed May 21, 2013, DOI: 10.1108/13639510810910599.

${ }^{71}$ Chu and Song, “Chinese Immigrants' Perceptions," Canada, 621.

${ }^{72}$ Ibid., 610. 
One way to rectify this problem is to employ a third party that acts as a medium between the police and ethnicized groups. Several academics agree with this assessment, and find that it is a successful tool for building community relationships and maintaining two-way communication. It is also purported as a good way to reach out to communities that were previously anti-pathetical to police. ${ }^{73}$ Canadian police services commonly utilize diversity liaison officers who have been educated on distinct cultural issues of their respective community, and possess some familiarity of other languages. ${ }^{74}$ Diversity liaison officers have been useful when dealing with the Aboriginal community. They have consulted with leaders in volatile communities, and utilized their cultural sensitivities to mitigate regional tensions. ${ }^{75}$ This demonstrates the effectiveness of what an intermediary can do to promote cooperation.

Popular discourses surrounding other ethnic, cultural, and religious groups have inhibited the development of community policing responses that promote two-way communication. For instance, it is difficult to develop effective policing strategies for Muslims because the vast majority of policing literature is devoted to counterterrorism responses. Basia Spalek mentioned that Muslims have been problematized in what is labelled as "new terrorism". ${ }^{76}$ She also stated that the government, the media, and security groups have initiated a discourse where young Muslims are framed into a "problem group". She concluded by purporting that police services need to incorporate the Muslim community into counterterrorism efforts by implementing a

\footnotetext{
${ }^{73}$ Martin Innes, "Policing Uncertainty: Countering Terror through Community Intelligence and Democratic Policing," American Academy of Political and Social Science 605 (2006): 1-20, accessed May 10, 2013, DOI: $10.1177 / 0002716206287118$.

${ }^{74}$ Stenning, "Policing the Cultural Kaleidoscope," 21.

${ }^{75}$ Chrismas, "The People are the Police," 463.

${ }^{76}$ Basia Spalek, "Community Policing, Trust, and Muslim Communities in Relation to "New Terrorism"," Politics \& Policy 38 (2010): 794-795, accessed May 21, 2013, DOI: 10.1111/j.1747-1346.2010.00258.x.
} 
"neighbourhood policing model", which is premised on the community identifying and reporting suspicious behaviour linked to terrorism. ${ }^{77}$

However, the question can be asked if community policing in Muslim communities should exclusively focus on counterterrorism initiatives. Spalek's article was entirely focused on community policing responses to terrorism, and at times, sensationalized the issue by using quoted descriptors to criticize the security discourse. Some academics have tried to steer the discussion in another direction. Dan Silk addressed the issue by stating that counterterrorism efforts need to be enforced through preventative measures, but he also cautioned that community policing cannot exclusively prioritize terrorism issues. ${ }^{78}$ He purported that there needs to be some consideration on how to form a collective vision. This can be difficult because the police and the Muslim community are faced with the conundrum of defining their mutual relationship without framing it under national security terms. ${ }^{79}$ Constructing and maintaining a relationship between these two entities is also fraught with issues involving trust.

William Lyons suggested that police services need to build trust with communities that are the least cooperative, and he provided specific mention of Arab and Muslim groups. ${ }^{80} \mathrm{He}$ found that the partnerships that police have with the community are the most efficient when they encourage information sharing and participation in difficult communities. According to Lyons, there is a major problem that obstructs this relationship from being developed and maintained. ${ }^{81}$ Of paramount concern is that police selectively build partnerships out of convenience. He

\footnotetext{
${ }^{77}$ Spalek, "Community Policing," 795.

${ }^{78}$ United States Department of Justice, Federal Bureau of Investigation, Community Policing to Prevent Violent Extremism, by Dan Silk (Washington, DC: FBI Publications, 2012. Accessed May 24, 2013), 1-2, http://www.fbi.gov/stats-services/publications/law-enforcement-bulletin/october-2012/leb-oct-2012.pdf.

${ }^{79}$ Silk, Community Policing to Prevent Violent Extremism, 1-2.

${ }^{80}$ William Lyons, "Partnerships, Information and Public Safety: Community Policing in a Time of Terror," Policing: An International Journal of Police Strategies and Management 25 (2002): 530-532, accessed May 25, 2013, DOI: 10.1108/13639510210437023.

${ }^{81}$ Lyons, "Partnerships, Information and Public Safety," 532-537.
} 
further commented on the matter by stating that the police tend to build relationships with groups that are the least likely to be beneficial in policing operations. However, there was no critical examination of Arab and Muslim communities, nor were there considerations about the possibility that they may be resistant to forming a partnership.

When examining some of the international examples on police-Muslim relationships, it appears as if trust is a contentious issue regarding the collection of information. For example, the Muslim Contact Unit (MCU) is a special counterterrorism group that was formed in England after the events of $9 / 11$ under a community policing orientation. ${ }^{82}$ The program was supposed to signify a departure from other counterterrorism initiatives, but it has been criticized for how it treats community members. Basia Spalek stated that they are seen as "informants" rather than "partners", and have been disconnected from the police. She interviewed a group of respondents that had some form of contact with the MCU unit, and the results indicated that the relationship between Muslims and the police had been characterized by mutual mistrust. ${ }^{83}$ One could argue that Spalek's suggestion for trust building did not give serious consideration for the security issues involved in establishing openness and transparency. Nonetheless, Spalek's assertion that the police have become disassociated from the community is shared by others. It is not limited to the MCU, but can be applied more broadly to policing services in general.

\section{METHOD}

This assertion is pervasive amongst the literature. Many studies have also expressed skepticism about community policing, and its ability to address the public's concerns. Few scholars have actually studied its implementation, and even considered using regional police

\footnotetext{
${ }^{82}$ Spalek, "Community Policing," 797.

${ }^{83}$ Ibid., 797-803.
} 
services as their units of analysis. ${ }^{84}$ In what follows, this section will provide a clear and succinct explanation of the analysis. It will begin with an introduction of the materials, and then provide an overview of the method.

The DRPS has produced enough documents regarding its community policing approach to make academic inquiry into the subject possible. Data was derived from publicly available sources. Firstly, documents from the DRPS's website have been retrieved which include the Durham Regional Police Service (DRPS) 2005 - 2010 Diversity Strategic Plan, Durham Regional Police Service (DRPS) 2012 - 2015 Diversity and Inclusivity Strategic Plan, and the November $5^{\text {th }} 2012$ Monitoring Report: Community Diversity. The former two documents outline the DRPS's strategy for addressing diverse groups, while the monitoring report assesses the progress of their initiatives. In addition, the analysis will also include information from the May $9^{\text {th }} 2011$ Monitoring Report: Community Policing, the April $10^{\text {th }} 2012$ Monitoring Report: Community Policing, and the April $8^{\text {th }} 2013$ Monitoring Report: Community Policing. These cross-sectional reports provide a thorough understanding of the DRPS's community policing strategy.

In order to establish a benchmark for what constitutes a community policing initiative, references will be repeatedly made from the OACP's document titled "Partnering for a Safe Community": Ontario's New Community Policing Model, which contains information about the OACP's Mobilization and Engagement Model of Community Policing. Additionally, this will be supplemented by a report from the Ministry of Community Safety and Correctional Services (MCSCS) titled A Safe, Strong, Secure Ontario: Ministry of Community Safety and Correctional Services Strategic Plan 2008-2013 and a manual written by the MCSCS and the OACP titled

\footnotetext{
${ }^{84}$ Chappell, "The Philosophical Versus Actual Adoption of Community Policing," 22.
} 
Crime Prevention in Ontario: A Framework for Action. These reports contain information about how community policing strategies should be framed, whom they should network with, and how they should adapt to changing population dynamics. It will also be useful in identifying errors and areas that are lacking appropriate responses. Furthermore, it is important to understand how these documents will be compared in the analysis.

The diverse array of sources in this study has made it possible to examine them in a comparative fashion. Given the nature of the information, a document analysis will be used to examine the data in the next section. More specifically, it will assess whether the DRPS has been able to address the concerns identified within the literature that pertain to the themes of police-citizen dialogue, police subculture, community issues, and perceptions of the police. This will identify whether the policing method is effective in addressing the needs of diverse ethnic groups. The other objective of the analysis is to clarify if the DRPS's format is representative of the OACP and MCSCS's vision of community policing in Ontario. This will be accomplished by assessing whether the DRPS method emulates these strategies. In summation, the analysis yielded results which suggest that the community policing format in Durham is a partial reflection of the OACP and MCSCS mandate, and that it has had modest success in addressing ethnicized group concerns. One of the main issues identified by respondents was the lack of engagement from the DRPS.

\section{RESULTS}

The May $9^{\text {th }} 2011$ Monitoring Report reinforced this point, and indicated very low levels of perceived support from the DRPS. This was especially true regarding the question about 
accessing victim services and support groups. ${ }^{85}$ Only $29 \%$ of respondents knew how to get into contact with them. Participants also noted that the police did not relay community safety issues in a timely manner. ${ }^{86}$ What this shows is that residents in Durham Region displayed low levels of confidence in the police. This finding was consistent across Ontario, and noted in the A Safe, Strong, Secure Ontario: Ministry of Community Safety and Correctional Services Strategic Plan 2008-2013 as a key concern for police agencies. ${ }^{87}$ Of paramount concern regarding the service's approach is that it has not outlined a strategy to raise public confidence levels, yet the MCSCS has stated that police agencies should follow the suggestions from the Goudge Inquiry. ${ }^{88}$

However, an even greater issue mentioned in the May $9^{\text {th }} 2011$ Monitoring Report was the lack of dialogue exchange between the police and the community. ${ }^{89}$ This raises the question as to whether the DRPS has established contacts with the right groups, and whether these relationships encourage civilian participation. It is also important to recall William Lyons's point that police agencies partner with communities that are the least likely to be beneficial. ${ }^{90}$ With respect to the DRPS, they had many partnerships within the community, but they did not offer an outlet for civilians to relay concerns about policing and crime. One of the main goals from the 2005 - 2010 Diversity Strategic Plan was to build community relations in order to

${ }^{85}$ Durham Regional Police Service, May $9^{\text {th }} 2011$ Monitoring Report: Community Policing (Whitby, ON: Durham Region, 2011), 6, http://www.drps.ca/upload_files/Community_Policing_Monitoring_Report_9_May_11_201161075543.pdf.

${ }^{86}$ Durham Regional Police Service, May $9^{\text {th }} 2011$ Monitoring Report, 6.

${ }^{87}$ Ministry of Community Safety and Correctional Services, A Safe, Strong, Secure Ontario: Ministry of Community Safety and Correctional Services Strategic Plan 2008-2013, (Toronto, ON: Government of Ontario, 2008), 8, http://www.mcscs.jus.gov.on.ca/stellent/groups/public/@mcscs/@www/@com/documents/webasset/ec069601.pdf.

${ }^{88}$ Ministry of Community Safety and Correctional Services, A Safe, Strong, Secure Ontario, 13.

${ }^{89}$ Durham Regional Police Service, May $9^{\text {th }} 2011$ Monitoring Report, 6.

${ }^{90}$ Lyons, "Partnerships, Information and Public Safety," 532-537. 
understand its needs, ${ }^{91}$ but the plan stopped short of providing a concrete explanation with regard to how this was meant to be carried out in practice.

This demonstrates that the DRPS does not have a viable plan to address this problem. In the report A Safe, Strong, Secure Ontario: Ministry of Community Safety and Correctional Services Strategic Plan 2008-2013, the MCSCS stated that improving upon police-citizen dialogue would allow police services to "make measurable progress in delivering responsive programming." 92 The overall objective of this approach would be to help create services that cater to the unique needs of Canada's ethnically diverse communities. Several examples of responsive programming were provided in the report which includes Crime Stoppers, Phone Busters, and also references to the Hate Crimes Community Working Group's Report. ${ }^{93}$ There are also options that could stimulate a local and informal dialogue exchange to address community concerns and crime related issues. A community consultative committee would grant citizens the opportunity to relay their concerns, critique police practices, identify community problems, and propose solutions. The DRPS could also introduce community forums which are formed to cover single issues, and due to their temporariness, are much cheaper than creating community consultative committees. ${ }^{94}$ They are viewed as being more effective than police committees, which tend to study the community as a homogenous social unit with a consensus on community values and crime responses. ${ }^{95}$

A concern for both community consultative committees and community forums is motivating participants to attend and making sure that the community knows they are invited to

${ }^{91}$ Durham Regional Police Services and Graybridge Malkam, Durham Regional Police Service (DRPS) 2005 - 2010 Diversity Strategic Plan, by Judy Laws, Gérard Étienne and Sara Delaney (Ottawa, ON: Graybridge Malkam, 2005), 17, http://www.drps.ca/upload_files/Diversity_Plan.pdf.

${ }_{92}$ Ministry of Community Safety and Correctional Services, A Safe, Strong, Secure Ontario, 14.

${ }^{93}$ Ibid., 14.

${ }^{94}$ Ben-Porat, Guy, "Policing Multicultural States," 423.

${ }^{95}$ Leighton, "Visions of Community Policing," 504. 
partake in these initiatives. Residents of Durham Region appeared to be affected by both problems depending on who you asked. Regarding the survey mentioned earlier, civilian participants displayed low levels of confidence that the DRPS provided them with opportunities to be involved in crime prevention. This was the lowest of all scores on the survey from civilians where only $24.2 \%$ mentioned that the police provided this option. ${ }^{96}$ Contrastingly, police participants voiced a similar opinion about citizens wanting to become part of crime control initiatives. The results indicated that $82.2 \%$ of DRPS employees did not feel that the community was willing to participate in crime control opportunities set out by the service. ${ }^{97}$ This finding is consistent with others from previous works such as Glaser and Denhardt's study, which also reported a lack of confidence in the public. ${ }^{98}$ In addition, representatives from the OACP reaffirmed this point and suggested that police "...can support, lead, provide a role model and assist in times of trouble but the 'community' itself has to step up and take responsibility-be accountable-for their safety and security...."99

Despite the fact that there had not been a viable solution introduced to counter this problem, at least the DRPS was aware that it existed due to the findings in the monitoring report. The question then is how to appropriately remedy the issue regarding the police and civilian lack of confidence in each other's willingness to partake in these initiatives. According to the $2005-$ 2010 Diversity Strategic Plan ${ }^{100}$ and the 2012 - 2015 Diversity and Inclusivity Strategic Plan, ${ }^{101}$ there needs to be some level of community engagement in order for the police to educate the

\footnotetext{
${ }^{96}$ Durham Regional Police Service, May $9^{\text {th }} 2011$ Monitoring Report, 6.

${ }^{97}$ Ibid., 6.

${ }^{98}$ Mark A. Glaser and Janet Denhardt, "Community Policing and Community Building." The American Review of Public Administration 40 (2010): 309-325, accessed October 8, 2013, DOI: 10.1177/0275074009340050.

99 Ontario Association of Chiefs of Police, "Preparing for a Safer Community," 8. http://www.wlu.ca/documents/45682/Ontario_Community_Policing_Model_NEW.pdf.

${ }^{100}$ Laws, Étienne and Delaney, 2005 - 2010 Diversity Strategic Plan, 13.

${ }^{101}$ Durham Regional Police Services and Graybridge Malkam, Durham Regional Police Service (DRPS) 2012 - 2015 Diversity and Inclusivity Strategic Plan, by Judy Laws (Ottawa, ON: Graybridge Malkam, 2012), 3, http://www.drps.ca/upload_files/Diversity_Plan.pdf.
} 
public about what they do. The plans mentioned that this may be part of a promotional initiative to engage the community, and be included in the short-term goals of the organization. It would also help eliminate any misconceptions or reservations that the public has about the DRPS or even the function of policing as a whole. In fact, this has been made a priority by the Province of Ontario which is why it is mentioned in the Crime Prevention In Ontario: A Framework for Action manual that;

Public education and awareness is an important tool for preventing crime and victimization. Actions such as using social/commercial media to educate communities about how they can avoid being victimized or how to identify the early signs of risk factors for crime in an individual can go a long way. Education and awareness campaigns can also play a strong role in enhancing the community's understanding of the benefits of social development and crime prevention. ${ }^{102}$

According to the OACP's Mobilization and Engagement Model of Community Policing, this is an integral part of community policing. The organization stated that this is achieved through the combination of community engagement and liaison. ${ }^{103}$ Some of the examples included within this strategy were monitoring at-risk groups and partnering in early intervention. Essentially, the DRPS has been able to participate in programs that utilize these tools simultaneously while educating the public too. A notable example is the Whitby After-School Program developed for R.A. Sennett Public School. ${ }^{104}$ The school was situated in a high-risk area where previous contact between youth and police had been absent. It began with one police officer, two teachers, and two program developers who constructed the program to address specific needs of

\footnotetext{
${ }^{102}$ Ministry of Community Safety and Correctional Services and Ontario Association of Chiefs of Police, Crime Prevention in Ontario: A Framework for Action (Toronto, ON: Government of Ontario, n.d.), 22, http://www.mcscs.jus.gov.on.ca/stellent/groups/public/@mcscs/@www/@ com/documents/webasset/ec157730.pdf. ${ }^{103}$ Ontario Association of Chiefs of Police, "Preparing for a Safer Community," 24.

${ }^{104}$ Durham Regional Police Service, April ${ }^{\text {th }} 2013$ Monitoring Report: Community Policing (Whitby, ON: Durham Region, 2013), 12, http://www.drps.ca/upload_files/Community_Policing_8_Apr_2013_201341610363.pdf.
} 
the community. Children were engaged in supervised educational activities in a safe environment that provided them with life experiences they would not have otherwise had the opportunity to gain. This program achieved enough success that it spread to other schools within the Durham Region.

Another aspect from the OACP's Mobilization and Engagement Model of Community Policing that is supposed to promote police-community interaction is the community mobilization and crime prevention strategy. ${ }^{105}$ One of the key points within it is to implement a problem-oriented policing approach, which is a major component of community policing. Problem-oriented-policing focuses upon issues that emerge from specific communities, and addresses them accordingly. This option can help stimulate police-citizen dialogue. However, some of the literature has found that police officers only identify small short-term problems, and that these issues are only identified through complaints rather than through proactive policing measures. ${ }^{106}$ Despite this criticism, some of the literature has identified that police officers strongly favour the tactical dimensions of problem-oriented-policing, and find this to be the most important aspect of community policing. ${ }^{107}$ The DRPS has highlighted this as strong priority, and demonstrated that they are committed to this strategy.

Between 2007 and 2011, the DRPS consistently trained frontline officers in problembased learning. This training program was meant to encourage members to utilize critical thinking skills as a means to understand social issues that affect the community, and how these conditions influence certain criminal behaviours. ${ }^{108}$ They also trained police officers on patrol

\footnotetext{
${ }^{105}$ Ontario Association of Chiefs of Police, "Preparing for a Safer Community," 24.

${ }^{106}$ Cordner and Perkins Biebel, "Problem Oriented Policing in Practice." 164-166.

107 Cheuprakobit, "Community Policing," 721.

${ }^{108}$ Durham Regional Police Service, April 10 2012 Monitoring Report: Community Policing (Whitby, http://www.drps.ca/upload_files/Community_Policing_Monitoring_Report_10_APR_2012_20125275146.pdf.
} ON: Durham Region, 2012), 4, 
techniques to effectively engage with the community, but the utility of this program lacked explanation in the report. Between the two programs, 427 officers were reported to have received at least some type of training relevant to community policing. This shows that the DRPS has effectively implemented problem-oriented-policing in training, and through the use of patrol techniques, have provided officers with the knowhow to proactively interact with the community.

Nonetheless, there are complications about how front-line officers are able to proceed in practice. The 2005 - 2010 Diversity Strategic Plan stated that officers were unable to establish appropriate connections with the community because of their rotation schedule. ${ }^{109}$ It further stated that police constables changed divisions every three years as part of the DRPS strategy. The report also mentioned that this policy was highly problematic because officers had only just ensconced a foothold in the community and set up basic connections before leaving. Short rotation schedules may prove to be problematic in the long term. There are many considerations that need to be made in these placements such as the officer's suitability, their desire to be there, and their ability to establish authority. ${ }^{110}$ Contrarily, Savvas Lithopolous and Rick Ruddell found evidence to support the notion that greater familiarity with the community may increase the use of enforcement practices. ${ }^{111}$ Regardless of whether this affects an officer's application of community policing, the DRPS has engaged in initiatives to provide frontline personnel with an understanding of the public's concerns.

The diversity strategic plan proposed the development of a database that would record cultural group issues. ${ }^{112}$ What this response was meant to do is highlight community concerns as

\footnotetext{
${ }^{109}$ Laws, Étienne and Delaney, 2005 - 2010 Diversity Strategic Plan, 11.

${ }^{110}$ Ben-Porat, Guy, "Policing Multicultural States," 420.

${ }^{111}$ Lithopolous and Ruddell, "Policing Isolated Aboriginal Communities," 445.

112 Ibid., 18.
} 
a part of the problem-oriented-policing approach. It would also allow police officers to jointly commit to each other's investigations in specific ethnic communities. At the same time, this response would enable the DRPS to meet the MCSCS's goal of utilizing technology to enhance service delivery by promoting interdepartmental and intradepartmental cooperation. ${ }^{113}$ While the plan may appear to be effective on paper, it should not be a substitute to proactive community involvement. Consider the fact that the goal of this strategy is to create a more person-centred approach. If the DRPS were to use this method, then it would not signify a development in community policing, but further advance its intelligence-led-policing capabilities.

It is also important to consider the negative consequences of introducing this tool. There is the potential that it may be used as a race-based profiling mechanism, which may undermine its purpose of serving a specific ethnic community's self-identified concerns. Another aspect to contemplate would be the cost of maintaining this database. Recall that there has been significant pressure on police services within the GTA to restructure their budgeting to appropriately manage scarce funds. ${ }^{114}$ The DRPS would have to deliberate the utility of this new community intelligence tool relative to its expense, and whether it would overlap with the already existing Canadian Police Information Centre archive. However, a community-ethnicdatabase cannot address all the problems inherent in interaction between ethnicized groups and the DRPS.

One of the concerns addressed in the $2005-2010$ Diversity Strategic Plan ${ }^{115}$ and the 2012 - 2015 Diversity and Inclusivity Strategic Plan was the issue of language barriers. ${ }^{116}$ This continued to be the greatest impediment to police-ethnic interaction, and from a policy

\footnotetext{
${ }^{113}$ Ministry of Community Safety and Correctional Services, A Safe, Strong, Secure Ontario, 13.

${ }^{114}$ Clarke, "Hands Firmly on the Steering Wheel," 474-477.

${ }^{115}$ Laws, Étienne and Delaney, 2005 - 2010 Diversity Strategic Plan, 13.

${ }^{116}$ Ibid., 13.
} 
perspective, there was an absence of protocol to address the issue. The DRPS plans did not provide specific details about the problem, and the policing models set out by the MCSCS and OACP neglected to address this issue altogether. In order to broach the subject, one must identify exactly where these barriers are most prevalent, and work towards mitigating them. The November $5^{\text {th }} 2012$ Monitoring Report stated that the DRPS had 50 officers that spoke 20 different languages. ${ }^{117}$ Seven of these foreign languages were included in the top ten most commonly spoken languages at home. A major concern regarding the linguistic capabilities of the DRPS is that three of the languages that had not been represented in the service were among the most commonly used. When the report was written there were no frontline officers with the capability of speaking Urdu, Tamil, and Tagalog. ${ }^{118}$ This shows that there is a sizeable portion of Durham Region that may encounter some difficulties in communicating with the police.

It is also evident that there are certain ethnic groups not represented in the DRPS. This is a genuine concern because one of the primary goals set out by the MCSCS was to create a more diversified workforce. ${ }^{19}$ Furthermore, it will be particular difficult to recruit qualified racialized applicants because many of them have been discouraged from applying. ${ }^{120}$ By including more diverse applicants, and more specifically, applicants representing the backgrounds of highly spoken foreign languages, the DRPS would be able to effectively remedy some of its linguistic barriers. The 2005 - 2010 Diversity Strategic Plan and the $2012-2015$ Diversity and Inclusivity Strategic Plan outlined methods that the DRPS should use in practice when reaching

${ }^{117}$ Durham Regional Police Service, November $5^{\text {th }} 2012$ Monitoring Report: Community Diversity (Whitby, ON: Durham Region, 2012), 4, http://www.drps.ca/upload_files/Diversity_Monitoring_Report_05_Nov_2012_20121121122328.pdf.

${ }^{118}$ Ibid., 4.

${ }^{119}$ Ministry of Community Safety and Correctional Services, A Safe, Strong, Secure Ontario, 15.

${ }^{120}$ Stephen B. Perrot, "Visible Minority Applicant Concerns and Assessment of Occupational Role in the Era of Community-based Policing," Journal of Community \& Applied Social Psychology 9 (1999): 339-353, accessed July 21, 2013, DOI: 10.1002/(SICI)1099-1298(199909/10)9:5<339::AID-CASP517>3.0.CO;2-R. 
out to a broader applicant pool. It was suggested that the organization should promote policing as a reputable career, and target ethnicized groups to help build positive attitudes about the profession. ${ }^{121}$ This may be achieved by engaging in activities such as outreach and diversity recruitment. ${ }^{122}$ Another area that the DRPS's plans targeted was barriers within the hiring practice.

One suggestion was to evaluate all résumés regardless of whether the applicants were qualified. ${ }^{123}$ The objective would be to ensure that there are no biases regarding which résumés are selected for review, and provide all applicants a fair opportunity to be evaluated. One study from the literature asked ethnicized applicants how police services could enhance hiring practices. The respondents stated that they could screen for morale fibre, increase internship programs, and establish formal contacts with diverse ethnic communities. ${ }^{124}$ As of January 2013 , the DRPS began its own initiative to monitor its diversity recruitment. All new civilian recruits were given the option to indicate their race upon hire, so the service would be able to monitor its diversity within the civilian ranks. ${ }^{125}$ Uniformed officers had already been provided this option, and the statistics indicated that $11 \%$ of the DRPS's constables were from racialized communities. While there may be new initiatives to include diverse ethnic groups into the service, several impediments exist, which threaten its ability to recruit, retain, and promote them.

The greatest obstacle to recruiting diverse ethnic groups for police constable positions is the hiring freeze that has lasted for several years. In November 2012, the DRPS reaffirmed that it was only seeking to hire civilian members, and at that time, did not schedule a new recruitment

\footnotetext{
${ }^{121}$ Laws, Étienne and Delaney, 2005 - 2010 Diversity Strategic Plan, 11.

${ }^{122}$ Ministry of Community Safety and Correctional Services, A Safe, Strong, Secure Ontario, 15.

${ }^{123}$ Laws, Étienne and Delaney, 2005 - 2010 Diversity Strategic Plan, 11.

124 Jain, Singh and Agocs, "Recruitment, Selection and Promotion," 62.

${ }^{125}$ Durham Regional Police Service, November $5^{\text {th }} 2012$ Monitoring Report, 3.
} 
drive for uniformed applicants in 2013. ${ }^{126}$ This finding showed that in the near future it will be difficult to raise the DRPS's ethnic diversification, and meet the goals set out by the MCSCS. It is also evident that racialized communities are limited with respect to how they may participate in law enforcement initiatives. Even if the DRPS resumes recruiting new police constables, and hires diverse ethnic applicants, there are concerns about how they will be integrated into the service.

The 2012 - 2015 Diversity and Inclusivity Strategic Plan suggested that the goals of fostering diversity and inclusivity have not been wholeheartedly endorsed by the organization. ${ }^{127}$ It also stated that the diversity coordinator was the only major supporter of the diversity initiatives. Commitment on behalf of senior leadership was described as "lacking", and this trend appeared to be more broadly applicable to the service. According to the report, "White officers" did not view themselves as part of diversity, and saw no reason to support the initiative. ${ }^{128}$ The "what's in it for me" rationale for diversity competence did not resonate with them, but the report attempted to addresses this issue by promoting the idea that all officers are diverse despite colour differences. This initiative may have been more useful had the organization attempted to define exactly what "White" is rather than rely on vague notions about the differentiations of skin colour. Even though the DRPS has addressed the MCSCS's goal of incorporating fairness and diversity principles into its planning activities, ${ }^{129}$ it is apparent that the DRPS's culture is resistant to diversity initiatives.

Perhaps the most effective strategy thus far was the various partnerships it formed with community organizations. They stemmed from a variety of categories, and included an array of

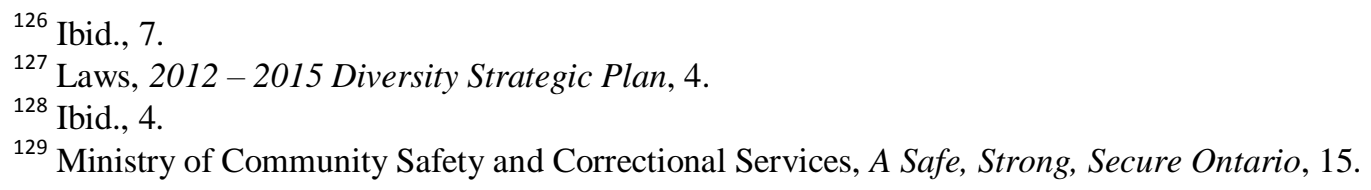


different audiences and members. Examples of the DRPS partnerships included organizations such as the Canadian Afghan Council, the Oshawa and Durham Region Métis Council, and the Tamil Academic Society of Durham. ${ }^{130}$ These partners worked with the DRPS as it sought to become associated with being a diverse and an inclusive organization. However, the extent to which these community agencies were able to collaborate with the police service had not been documented in any of the diversity or community policing monitoring reports.

The strongest evidence to suggest that community organizations in Durham Region had some involvement in community policing was found in the May $9^{\text {th }} 2011$ Monitoring Report. It stated that various agencies were able to participate in crime prevention initiatives. This is consistent with the OACP's goal of addressing the social antecedents of crime. ${ }^{131}$ There are several examples where the DRPS has been able to engage such measures while utilizing its community partnerships. For instance, the Central East Division (17) exercised a problemoriented-policing approach to addressing prostitution and its related social ills. ${ }^{132}$ The DRPS responded by collaborating with several organizations to tackle the issue, and included community groups such as the Celina/Albert Street Neighborhood Association, the Salvation Army, the Pinewood Centre, and the Distress Centre Durham. Thus, the service's initiative participated with community organizations in order to address a wider social problem.

It also demonstrated the importance of municipalities in developing crime prevention strategies. They are well situated to work with the local population, and develop community based programs that address those needs and conditions. ${ }^{133}$ The initiative is also consistent with the community policing objective stated by Matthew Scheider, Robert Chapman, and Amy

\footnotetext{
${ }^{130}$ Durham Regional Police Service, November $5^{\text {th }} 2012$ Monitoring Report, 10.

${ }^{131}$ Ontario Association of Chiefs of Police, "Preparing for a Safer Community," 14.

${ }^{132}$ Durham Regional Police Service, May $9^{\text {th }} 2011$ Monitoring Report, 5.

${ }^{133}$ Ministry of Community Safety and Correctional Services and Ontario Association of Chiefs of Police, Crime Prevention in Ontario, 17-18.
} 
Schapiro, where local solutions are created to address local problems. ${ }^{134}$ In the case of Durham Region, the example demonstrated effective interagency and coordinated service delivery. By collaboratively working with community agencies, police services will be able to better address crime and its underlying social phenomena. These agencies are also particularly attuned to dealing with diversity, which is an issue the DRPS has struggled with. This is evident in its conceptualization of generic racial categories, and also its ability to promote diversity initiatives.

\section{DISCUSSION}

The 2005 - 2010 Diversity Strategic Plan suggested that senior leadership should promote diversity within the uniformed division. ${ }^{135}$ The objective of this plan would be to construct the notion that diversity is a strategic advantage for the organization. In a view contrary to the one held by the service, Guy Ben-Porat purported that younger officers were more responsive to multicultural settings than were senior officers. ${ }^{136} \mathrm{He}$ also concluded that many of the more experienced officers were resistant to change. With this understanding, it would appear nonsensical to appeal to the senior ranks to promote diversity within the uniformed division.

This also relates to one of the other problems that the DRPS has been forced to confront. Resistance to diversity initiatives and other community policing endeavours from frontline officers may be broadly attributable to police culture. The diversity reports offered little to confront this issue, and were largely neglectful in mentioning its presence altogether, but the culture ultimately promotes resistance to change. Larry Coutts, Frank Schneider, and Claudia Tenuta stated that officers that had been accustomed to professional policing were dismissive of

\footnotetext{
${ }^{134}$ Scheider, Chapman, and Schapiro, "Towards the Unification of Policing Innovations," 696.

${ }^{135}$ Laws, Étienne and Delaney, 2005 - 2010 Diversity Strategic Plan, 19.

${ }^{136}$ Ben-Porat, Guy, "Policing Multicultural States," 422.
} 
community policing, and even argued that it was "soft" on crime. ${ }^{137}$ According to the authors, this resistive action from senior officers was influenced by how they were inducted into policing, and at the time, police services exercised the professional policing approach. They also mentioned that as more officers begin to retire, it will be especially important to cultivate the community policing orientation in new recruits. Finding ways for police officers to positively interact with the community, and equally important, diverse ethnic groups, can be an operose challenge.

Police services often use anti-racial profiling training and cultural sensitivity training to equip officers with a general understanding of how to approach diverse ethnic groups. The DRPS opted to employ this type of educational tool by introducing an Anti-Racial Profiling Electronic Learning Module, where officers were required to complete diversity and inclusivity training. ${ }^{138}$ This module was intended to instruct officers on the difference between criminal and racial profiling, the promotion of diversity and inclusivity amongst peers, and how to engage with youth in an ethnically diverse environment. Officers were given a deadline to complete the training, and at the time of the report being written, 65 members had already begun the module. Although it appears to be valid in theory, there must be some consideration regarding its effectiveness in practice.

What can be inferred from the literature is that some scholars have been critical about the efficiency of short term training modules. Curt Griffiths has been particularly pessimistic about how cultural sensitivity education is carried out in practice. He stated that previous training regimes were far too short and insufficient to prepare new recruits for interaction in diverse

\footnotetext{
${ }^{137}$ Coutts, Schneider and Tenuta, "Recruiting Community Policing Officers", 2631-2639.

${ }^{138}$ Durham Regional Police Service, November $5^{\text {th }} 2012$ Monitoring Report, 6-7.
} 
environments. ${ }^{139}$ This criticism is also applicable to the DRPS. The service's training only provided officers with a half-day program, and included a brief question and answer period with a diversity officer. ${ }^{140}$ Additionally, the Front Line Supervisor Course included diversity issues as a topic, but the thoroughness of this training lacked clarity.

Barbra Perry also expressed concern about the efficiency of these modules. She mentioned that there are few studies that examine whether they have positively affected the cultural sensitivities of police officers. ${ }^{141}$ Thus, the logical conclusion would be to implement some form of post-educational measurement, and assess whether they have affected the mindset of frontline personnel that have undergone training. This would inform the DRPS about the effectiveness of its training programs. Another aspect to consider is if its teaching format for cultural sensitivity is efficient. Valerie Pruegger and Tim Rogers mentioned that teaching cultural competency in a purely lecture based format appeared to be ineffective. ${ }^{142}$ Their study cited that lecture materials were much more useful when supplemented with experiential exercises because it provided participants with a practical element to engage in behaviour modelling. It would also be beneficial for the DRPS to coordinate its cultural sensitivity training and diversity recruitment together. One of the goals from the MCSCS was to develop a workforce that is both culturally responsive to diverse ethnic groups and representative of the community's demographics. ${ }^{143}$ With respect to DRPS policy, the service has already addressed these two issues in the 2005 - 2010 Diversity Strategic Plan and the $2012-2015$ Diversity and

${ }^{139}$ Curt T. Griffiths, Gregory Saville, Darryl S. Wood, and Evelyn Zellerer, "Policing the Baffin Region: Findings from the Baffin Region Crime and Justice Study," (Simon Fraser University, Criminology Research Centre, 1995), 40-42, http://www.curtgriffiths.com/pdfs/Policing\%20in\%20the\%20Arctic.pdf.

${ }^{140}$ Laws, Étienne and Delaney, 2005 - 2010 Diversity Strategic Plan, 12.

${ }^{141}$ Perry, "Policing Hate Crime in a Multicultural Society," 133.

${ }^{142}$ Valerie J. Preugger and Tim B. Rogers, "Cross-Cultural Sensitivity Training: Methods and Assessment," International Journal of Intercultural Relations 18 (1994): 370-371, accessed October 5, 2013, DOI: 10.1016/0147-1767(94)90038-8.

${ }^{143}$ Ministry of Community Safety and Correctional Services, A Safe, Strong, Secure Ontario, 15. 
Inclusivity Strategic Plan. The main issue is that both endeavours have been met with little avail. This is not the only example where the DRPS has had a disconnection between its policies and frontline successes.

There were also problems associated with its Multi-Cultural Community Liaison Committee. The goal of this group was to provide the DRPS with access to new areas that had previously been inaccessible. ${ }^{144}$ However, it was formed in absence of an organizational vision and mission statement. Perhaps it was even more problematic that in the 2012-2015 Diversity and Inclusivity Strategic Plan, the DRPS had yet to develop concrete rules and responsibilities for the committee. ${ }^{145}$ Even though the organization encountered difficulties in implementing community policing, there were other areas within this approach where it was more successful.

The DRPS has been able to meet the goal of information sharing with other police services. Specifically, the Crime Prevention in Ontario: A Framework for Action manual stated that collaboratively addressing a social problem allows agencies to combine ideas, resources, and practices. ${ }^{146}$ It also mentioned that it would target the issue on multiple fronts, thereby producing effective long term measures. An example where the DRPS has been able to engage in this type of partnership is with the RCMP. The rationale behind its formation is that the generic community policing orientation has not been efficient, and the DRPS and the RCMP recognized that they shared a common interest in addressing specific community problems. ${ }^{147}$ Thus, it was strategic to develop a partnership that would be mutually beneficial. This

\footnotetext{
${ }^{144}$ Laws, Étienne and Delaney, 2005 - 2010 Diversity Strategic Plan, 13.

${ }^{145}$ Laws, 2012 - 2015 Diversity Strategic Plan, 7.

${ }^{146}$ Ministry of Community Safety and Correctional Services and Ontario Association of Chiefs of Police, Crime Prevention in Ontario, 26.

${ }^{147}$ John Edward Deukmedjian and Willem de Lint, "Community into Intelligence: Resolving Information Uptake in the RCMP," Policing \& Society 17 (2007): 248, accessed May 15, 2013, DOI: 10.1080/10439460701497337.
} 
partnership signified a development within the DRPS's community policing orientation, and included elements from intelligence-led-policing in its information sharing.

\section{CONCLUSION}

For this reason, it is worth revisiting whether community policing is the most suitable approach. The OACP addressed this subject in its document "Partnering for a Safe Community": Ontario's New Community Policing Model. It stated that communities must be examined individually because each one has different needs. ${ }^{148}$ Moreover, the OACP mentioned that high-demand communities are particularly vulnerable because they have fewer resources and positive engagements with the police. A major concern with this is that many of these communities are ethnically diverse, and they are one of several marginalized groups which constitute the largest client base that Ontario police agencies serve. ${ }^{149}$ It is also problematic that high priority areas are the most likely areas to encounter racial profiling. ${ }^{150}$ After examining the Mobilization and Engagement Model of Community Policing, it is evident that there are strong differences in how safe communities and high-risk communities are policed. Safe communities are largely policed through community-led problem solving initiatives, which is characteristic of the community policing method. ${ }^{151}$ On the other hand, high-demand areas have coordinated police responses, which include professional policing, intelligence-led policing, and community policing.

What the OACP model has demonstrated is that each region has specific needs, and that each community varies in its ability to meet these requirements. At the very least, it can be

\footnotetext{
${ }^{148}$ Ontario Association of Chiefs of Police, "Preparing for a Safer Community," 10-11.

${ }^{149}$ Ministry of Community Safety and Correctional Services, A Safe, Strong, Secure Ontario, 11.

${ }^{150}$ Satzewich and Shaffir, "Racism versus Professionalism," 209.

${ }^{151}$ Ontario Association of Chiefs of Police, "Preparing for a Safer Community," 35.
} 
inferred that no single policing orientation can be universally and independently applied given the differing requirements of each region and police service. Much of the literature has suggested that a police service's approach is exclusively associated with one policing approach or the other, and that community policing is superior to intelligence-led-policing and professional policing without thoroughly examining the methods in a comparative fashion. John Murphy was one of the few scholars that gave serious consideration to a layered approach, but his rationale for community policing being the dominant orientation in a collaborative framework lacked sufficient explanation about why its prioritization was necessitated. Until academics begin to consider the practical capabilities of each police force, and that societal requirements are fluid in nature due to evolving social issues, there will be repeated misunderstandings in the literature about how to retrofit policing practices for Canada's diverse society. 


\section{BIBLIOGRAPHY}

Ben-Porat, Guy. "Policing Multicultural States: Lessons from the Canadian Model." Policing and Society 18 (2008): 411-425. Accessed May 24, 2013. DOI: 10.1080/10439460802094686.

Black, Pamela J. and Camilla J. Kari. "Policing Diverse Communities: Do Gender and Minority Status Make a Difference?." Journal of Ethnicity in Criminal Justice 8 (2010): 216-229. Accessed May 8, 2013. DOI: 10.1080/15377938.2010.502848.

Bullock, Karen. "Community, Intelligence-led Policing and Crime Control." Policing \& Society 23 (2013): 125-144. Accessed May 25, 2013. DOI: 10.1080/10439463.2012.671822.

Cao, Liqun. "Visible Minorities and Confidence in the Police." Canadian Journal of Criminology and Justice 53 (2011): 1-26. Accessed May 8, 2013. DOI: 10.1353/ccj.2011.0014.

Chappell, Allison T. "The Philosophical Versus Actual Adoption of Community Policing." Criminal Justice Review 34 (2009): 5-28. Accessed August 27, 2013. DOI:

$10.1177 / 0734016808324244$.

Cheuprakobit, Sutham. "Community Policing: Training, Definitions, and Policy Implications." Policing: An International Journal of Police Strategies \& Management 25 (2002): 709-725. Accessed September 1, 2013. DOI: 10.1108/13639510210450640.

Chrismas, Robert. "The People are the Police: Building Trust with Aboriginal Communities in Contemporary Canadian Society." Canadian Public Administration 55 (2012): 451-470. Accessed May 18, 2013. DOI: 10.1111/j.1754-7121.2012.00231.x.

Chu, Doris and John Huey-Long Song. "Chinese Immigrants' Perceptions of the Police in Toronto, Canada." Policing: An International Journal of Police Strategies \& Management 31 (2008): 610-630. Accessed May 21, 2013. DOI: 10.1108/13639510810910599.

Clairmont, Don. "Community Based Policing: Implementation and Impact." Canadian Journal of Criminology 33 (1991): 469-484. Accessed May 10, 2013.

http://www.heinonline.org.ezproxy.lib.ryerson.ca/HOL/Page?page=469\&handle=hein.journals\% 2 Fcjccj33\&collection=journals

Clarke, Curtis A. "Between a Rock and a Hard Place: RCMP Organizational Change." Policing: An International Journal of Police Strategies \& Management 25 (2002): 14-31. Accessed October 5, 2013. DOI: 10.1108/13639510210417872.

Clarke, Curtis A. "Hands Firmly on the Steering Wheel: Restructuring Metro Toronto Police Service." Policing: An International Journal of Police Strategies \& Management 26 (2003) 473489. Accessed October 8, 2013. DOI: 10.1108/13639510310489502. 
Cordner, Gary and Elizabeth Perkins Biebel. "Problem Oriented Policing in Practice." Criminology and Public Policy 4 (2005): 155-180. Accessed August 27 2013. DOI: 10.1111/j.1745-9133.2005.00013.x.

Coutts, Larry, M., Schneider, Frank, W. and Claudia Tenuta. "Recruiting Community Policing Officers: Reaching Out to a Broader Applicant Pool." Journal of Applied Social Psychology 34 (2004): 2629-2642. Accessed May 8, 2013. DOI: 10.1111/j.1559-1816.2004.tb01996.x.

Dauvergne, Mia and Geoffrey Li. "Homicide in Canada, 2005." Juristat: Canadian Centre for Justice Statistics 26 (2006): 1-25. Accessed October 5, 2013. http://search.proquest.com.ezproxy.lib.ryerson.ca/docview/216180255.

Deukmedjian, John Edward and Willem de Lint. "Community into Intelligence: Resolving Information Uptake in the RCMP.” Policing \& Society 17 (2007): 239-256. Accessed May 15, 2013. DOI: $10.1080 / 10439460701497337$.

Dickson-Gilmore, Jane. "Aboriginal Communities and Crime Prevention: Confronting the Challenges of Organized Crime.” IPC Review 1 (2007): 89-110. Accessed June 2, 2013. http://www.sciencessociales.uottawa.ca/ipc/pdf/kr4-dickson-gilmore.pdf.

Durham Regional Planning Department. Durham Region Demographics: Social Characteristics. Whitby, ON: Durham Region, 2006. http://www.durham.ca/departments/planed/planning/stats-nfacts/census/2006/charts/SocialCharacteristics.pdf.

Durham Region Planning Department. "Overview of Durham Region.” Accessed June 2, 2013. http://www.durham.ca/default.asp?nr=/corpoverview/overview.htm\&setFooter=/includes/corpFo oter.inc.

Durham Regional Police Service and Graybridge Malkam. Durham Regional Police Service (DRPS) 2005 - 2010 Diversity Strategic Plan, by Judy Laws, Gérard Étienne and Sara Delaney. Ottawa, ON: Graybridge Malkam, 2005. http://www.drps.ca/upload_files/Diversity_Plan.pdf

Durham Regional Police Service and Graybridge Malkam. Durham Regional Police Service (DRPS) 2012 - 2015 Diversity and Inclusivity Strategic Plan, by Judy Laws. Ottawa, ON: Graybridge Malkam, 2012. http://www.drps.ca/upload_files/Diversity_Plan.pdf .

Durham Regional Police Service. April $8^{\text {th }} 2013$ Monitoring Report: Community Policing. Whitby, ON: Durham Region, 2013. http://www.drps.ca/upload_files/Community_Policing_8_Apr_2013_201341610363.pdf.

Durham Regional Police Service. April 10 2012 Monitoring Report: Community Policing. Whitby, ON: Durham Region, 2012. http://www.drps.ca/upload_files/Community_Policing_Monitoring_Report_10_APR_2012_2012 5275146.pdf. 
Durham Regional Police Service. May $9^{\text {th }} 2011$ Monitoring Report: Community Policing. Whitby, ON: Durham Region, 2011.

http://www.drps.ca/upload_files/Community_Policing_Monitoring_Report_9_May_11_2011610 75543.pdf.

Durham Regional Police Service. November $5^{\text {th }} 2012$ Monitoring Report: Community Diversity. Whitby, ON: Durham Region, 2012.

http://www.drps.ca/upload_files/Diversity_Monitoring_Report_05_Nov_2012_20121121122328 .pdf.

Ericson, Richard V. and Kevin D. Haggerty. Policing the Risk Society. Toronto: University of Toronto Press, 1997.

Fleras, Augie. "“‘From Mosaic to Multiversality”: Repriming Multicultural Governance in a Postnational Canada." Canadian Ethnic Studies 43 (2011): 17-39. Accessed October 8, 2013. DOI: $10.1353 /$ ces.2011.0004.

Gabor, Thomas. "Inflammatory Rhetoric on Police Profiling Can Undermine Police Services." Canadian Journal of Criminology and Justice 46 (2004): 457-466. Accessed May 24, 2013. http://web.ebscohost.com.ezproxy.lib.ryerson.ca/ehost/pdfviewer/pdfviewer?sid=ea115eae-4b1346cd-857e-cdb7be99fee8\%40sessionmgr104\&vid=2\&hid=125.

Glaser, Mark A. and Janet Denhardt. "Community Policing and Community Building." The American Review of Public Administration 40 (2010): 309-325. Accessed October 8, 2013. DOI: 10.1177/0275074009340050.

Griffiths, Curt T., Gregory Saville, Darryl S. Wood, and Evelyn Zellerer. "Policing the Baffin Region: Findings from the Baffin Region Crime and Justice Study." Simon Fraser University, Criminology Research Centre, 1995. http://www.curtgriffiths.com/pdfs/Policing\%20in\%20the\%20Arctic.pdf.

Innes, Martin. "Policing Uncertainty: Countering Terror through Community Intelligence and Democratic Policing." American Academy of Political and Social Science 605 (2006): 1-20. Accessed May 10, 2013. DOI: 10.1177/0002716206287118.

Ipperwash Inquiry. Discussion Paper on Police/Government Relations, by Nye Thomas. Toronto, ON: Ministry of the Attorney General, 2006.

http://www.attorneygeneral.jus.gov.on.ca/inquiries/ipperwash/policy_part/discussion/pdf/Ipperw ashPolicingOccupations_DiscussionPaper_June2006.pdf.

Ipperwash Inquiry. Discussion Paper on Policing Occupations and Police Aboriginal Relations, by Nye Thomas. Toronto, ON: Ministry of the Attorney General, 2006.

http://www.attorneygeneral.jus.gov.on.ca/inquiries/ipperwash/policy_part/discussion/pdf/Ipperw ashPolicingOccupations_DiscussionPaper_June2006.pdf.

Jain, Harish C., Parbduyal Singh and Carol Agocs. "Recruitment, Selection and Promotion 
of Visible-minority and Aboriginal Police Officers in Selected Canadian Police Services." Canadian Public Administration 42 (2000): 46-74. Accessed May 12, 2013. DOI:

10.1111/j.1754-7121.2000.tb01560.x.

Leighton, Barry N. "Visions of Community Policing: Rhetoric and Reality in Canada." Canadian Journal of Criminology 33 (1991): 485-522. Accessed August 27, 2013. http://www.heinonline.org.ezproxy.lib.ryerson.ca/HOL/Page?page $=485 \&$ handle $=$ hein.journals $\%$ 2 Fcjccj33\&collection=journals.

Lithopolous, Savvas and Rick Ruddell. "Policing Isolated Aboriginal Communities: Perspectives of Canadian Officers." Policing: An International Journal of Police Strategies \& Management 34 (2011): 434-453. Accessed May 21, 2013. DOI: 10.1108/13639511111157500.

Lyons, William. "Partnerships, Information and Public Safety: Community Policing in a Time of Terror." Policing: An International Journal of Police Strategies \& Management 25 (2002): 530542. Accessed May 25, 2013. DOI: 10.1108/13639510210437023.

Macguire, Edward and Stephen Mastrofski. "Patterns of Community Policing in the United States." Police Quarterly 3 (2000): 4-45. Accessed August 7, 2013. DOI: $10.1177 / 1098611100003001001$.

McCaslin, Wanda D. And Yvonne Boyer. "First Nations Communities at Risk and in Crisis: Justice and Security." Journal of Aboriginal Health 5 (2009): 61-87. Accessed May 24, 2013. http://www.naho.ca/documents/journal/jah05_02/05_02_03_Communities.pdf.

McMurray, Adela J., Azharul Karim and Greg Fisher. "Perspectives on the Recruitment and Retention of Culturally and Linguistically Diverse Police." Cross Cultural Management: An International Journal 17 (2010): 193-210. Accessed June 6, 2013. DOI:

$10.1108 / 13527601011038741$.

Melchers, Ron. "Do Toronto Police Engage in Police Profiling?.” Canadian Journal of Criminology and Justice 45 (2003): 347-366. Accessed June 11, 2013.

http://search.proquest.com.ezproxy.lib.ryerson.ca/docview/216107956.

Ministry of Community Safety and Correctional Services. A Safe, Strong, Secure Ontario: Ministry of Community Safety and Correctional Services Strategic Plan 2008-2013. Toronto, ON: Government of Ontario, 2008.

http://www.mcscs.jus.gov.on.ca/stellent/groups/public/@mcscs/@www/@com/documents/weba sset/ec069601.pdf.

Ministry of Community Safety and Correctional Services and Ontario Association of Chiefs of Police. Crime Prevention in Ontario: A Framework for Action. Toronto, ON: Government of Ontario, n.d..

http://www.mcscs.jus.gov.on.ca/stellent/groups/public/@mcscs/@www/@com/documents/weba sset/ec157730.pdf. 
Murphy, Christopher. "“'Securitizing” Canadian Policing: A New Policing Paradigm For the Post 9/11 Security State?." The Canadian Journal of Sociology 32 (2007): 449-475. Accessed May 8, 2013. DOI: 10.1353/cjs.0.0022.

Murray, John. "Policing Terrorism: A Threat to Community Policing or Just a Shift in Priorities?." Police Practice and Research 6 (2005): 347-361. Accessed May 11, 213. DOI: $10.1080 / 15614260500293986$.

Nettelbeck, Amanda and Russell Smandych. "Policing Indigenous People on Two Colonial Frontiers: Australia's Mounted Police and Canada's North West Mounted Police." The Australia and New Zealand Journal of Criminology 43 (2010): 356-375. Accessed December 12, 2013. http://go.galegroup.com.ezproxy.lib.ryerson.ca/ps/i.do?action=interpret\&id=GALE\%7CA23783 $8149 \& v=2.1 \& u=r p u \_m a i n \& i t=r \& p=A O N E \& s w=w \&$ authCount $=1$.

O’Connor, Christopher. "Citizen Attitudes Towards the Police in Canada.” Policing: An International Journal of Police Strategies \& Management 31 (2008): 578-595. Accessed May 8 2013. DOI: 10.1108/13639510810910571.

O’Malley, Pat and Darren Palmer. "Post-Keynesian Policing." Economy and Society 25 (1996): 137-155. Accessed October 13, 2013. DOI: 10.1080/03085149600000007.

Ontario Association of Chiefs of Police. "Preparing for a Safer Community: Ontario's New Community Policing Model." Wilfrid Laurier University website. Accessed September 3, 2013. http://www.wlu.ca/documents/45682/Ontario_Community_Policing_Model_NEW.pdf.

Pasternak, Shiri, Sue Collis and Tia Dafnos. "Criminalization at Tyendinaga: Securing Canada's Colonial Property Regime through Specific Land Claims." Canadian Journal of Law and Society 28 (2013): 65-81. Accessed December 12, 2013. DOI: 10.1017/cls.2013.4.

Perrott, Stephen B. "Visible Minority Applicant Concerns and Assessment of Occupational Role in the Era of Community-based Policing." Journal of Community \& Applied Social Psychology 9 (1999): 339-353. Accessed July 21, 2013. DOI: 10.1002/(SICI)10991298(199909/10)9:5<339::AID-CASP517>3.0.CO;2-R.

Perry, Barbra. "Policing Hate Crime in a Multicultural Society: Observations from Canada." International Journal of Law, Crime and Justice 38 (2010): 120-140. Accessed October 5, 2013. DOI: 10.1016/j.ijlcj.2010.10.004.

Police Executive Research Forum. Defining the "Community" in Community Policing, by Daniel W. Flynn. Washington, DC: Police Executive Research Forum, 1998. http://www.policeforum.org/library/community-policing/cp.pdf.

Preugger, Valerie J. and Tim B. Rogers. "Cross-Cultural Sensitivity Training: Methods and Assessment." International Journal of Intercultural Relations 18 (1994): 369-387. Accessed October 5, 2013. DOI: 10.1016/0147-1767(94)90038-8. 
Rankin, Jim, Jennifer Quinn, Michelle Shephard, Scott Simmie and John Duncanson. "Singled Out." Toronto Star. October 19, 2002. Accessed June 11, 2013.

http://www.thestar.com/news/gta/knowntopolice/singled-out.html.

Ratcliffe, Jerry H. "Intelligence-led Policing." Australian Institute of Criminology 248 (2003): 16. Accessed August 12, 2013. http://www.aic.gov.au/documents/7/E/8/\%7B7E86F617-91514300-B53B-D45F6F876360\%7Dti248.pdf.

Rohe, William M., Richard E. Adams and Thomas A. Arcury. "Community Policing and Planning." Journal of the American Planning Association 67 (2001): 78-90. Accessed June 10, 2013. http://search.proquest.com.ezproxy.lib.ryerson.ca/docview/229642456.

Rowe, Michael. "Policing Diversity: Themes and Concerns from the Recent British Experience." Police Quarterly 5 (2002): 424-446. Accessed May 8, 2013. DOI: 10.1177/109861102237689.

Satzewich, Vic and William Shaffir. "Racism versus Professionalism: Claims and Counterclaims about Racial Profiling." Canadian Journal of Criminology and Justice 51 (2009): 199226. Accessed June 11, 2013. DOI: 10.1353/ccj.0.0053.

Scheider, Matthew C., Robert Chapman, and Amy Schapiro. "Towards the Unification of Policing Innovations under Community Policing." Policing: An International Journal of Police Strategies \& Management 32 (2009): 694-718. Accessed September 3, 2013. DOI: 10.1108/13639510911000777.

Seagrave, Jayne. "Defining Community Policing." American Journal of Police 15 (1996): 1-22. Accessed May 8, 2013. DOI: 10.1108/07358549610122476.

Spalek, Basia. "Community Policing, Trust, and Muslim Communities in Relation to "New Terrorism”." Politics \& Policy 38 (2010): 789-815. Accessed May 21, 2013. DOI: 10.1111/j.1747-1346.2010.00258.x.

Stenning, Phillip C. "Policing the Cultural Kaleidoscope: Recent Canadian Experience." Police and Society 7 (2003): 13-47.

Terpstra, Jan. "Governance and Accountability in Community Policing." Crime Law and Social Change 55 (2011): 87-104. Accessed October 3, 2013. DOI: 10.1007/s10611-011-9272-y.

Thayer, Ralph and Michael K. Reynolds. "Community Oriented Policing." Journal of Planning Literature 12 (1997): 93-105. Accessed May 8, 2013. DOI: 10.1177/088541229701200105.

United States Department of Justice, Federal Bureau of Investigation, Community Policing to Prevent Violent Extremism, by Dan Silk, Washington, DC: FBI Publications, 2012. Accessed May 24, 2013. http://www.fbi.gov/stats-services/publications/law-enforcement-bulletin/october2012/leb-oct-2012.pdf. 
Walker, Peter B. and Peter C. Kratcoski. "Cross Cultural Perspective on Police Values and Police-Community Relations." Criminal Justice Review 10 (1985): 17-24. Accessed May 8, 2013. DOI: 10.1177/073401688501000103.

Wortley, Scot and Akwasi Owusu-Bempah. "Unequal Before the Law: Immigrant and Racial Minority Perceptions of the Canadian Criminal Justice System." International Migration and Integration 10 (2009): 447-473. Accessed May 24, 2013. DOI: 10.1007/s12134-009-0108-x.

Wortley, Scot and Julian Tanner. Data, Denials, and Confusion: The Racial Profiling Debate in Toronto. Canadian Journal of Criminology and Justice 45 (2003): 367-369. Accessed May 24, 2013. http://search.proquest.com.ezproxy.lib.ryerson.ca/docview/216094986\#.

Wortley, Scot and Julian Tanner. "Inflammatory Rhetoric? Baseless Accusations? A Response to Gabor's Critique of Racial Profiling Research in Canada." Canadian Journal of Criminology and Justice 47 (2005): 581-609. Accessed May 24, 2013. http://search.proquest.com.ezproxy.lib.ryerson.ca/docview/216104601.

Wu, Yuning, Ivan Y. Sun and Brad W. Smith. "Race, Immigration, and Policing: Chinese Immigrants' Satisfaction with Police." Justice Quarterly 28 (2011): 745-774. Accessed May 16, 2013. DOI: 10.1080/07418825.2010.535009. 